\section{Kastamonu Eğitim Dergisi Kastamonu Education Journal}

Temmuz 2019 Cilt:27 Sayı:4 kefdergi.kastamonu.edu.tr
Başvuru Tarihi/Received: 7.08.2018

Kabul Tarihi/Accepted: 6.11.2018 DOI: $10.24106 /$ kefdergi.3275

\title{
Öğretmenlerin Eleştirel Düşünme Eğilimlerinin Örgütsel Bağlılık Üzerindeki Etkisi ${ }^{1}$
}

\section{The Influence of Teachers' Critical Thinking Tendencies on Organizational Commitment}

\author{
Cennet KURBAN ${ }^{2}$, Türkay Nuri TOK ${ }^{3}$
}

\section{Öz}

Bu araştırmada öğretmenlerin eleştirel düşünme eğilimlerinin, örgütsel bağlıık düzeylerine etkisi araştrıımıştır. Araştırmanın örneklem grubu Denizli iline bağlı bir ilçede görev yapan 185 öğretmenden oluşmaktadır. Öğretmenlerin eleştirel düşünme eğilimlerini ölçmek amacıyla Eleştirel Düşünme Eğilim Ölçeği'nden, örgütsel bağlılık düzeylerini ölçmek için ise Meyer ve Allen'in geliştirdiği Örgütsel Bağlılık Ölçeği'nden yararlanılmıştr. Eleştirel düşünme eğilimi değişkeninin örgütsel bağ|ıık üzerinde, kıdem yılının normatif bağlılık boyutu üzerinde ve okulda çalışma süresinin devam bağlılığı üzerinde anlamlı yordayıcı olduğu sonucuna ulaşılmıştr. Bilişsel olgunluk boyutunun devam bağ|ılı̆̆ı, duygusal bağ|ııı ve normatif bağ|ılık boyutlarında anlamlı bir etki oluşturduğu ve katılım boyutunun devam bağlılık boyutu üzerinde anlamlı bir yordayıcı olduğu görülmektedir.

Anahtar Kelimeler: Eleştirel Düşünme, Örgütsel Bağ|lık, Öğretmen

\section{Abstract}

In this study, the effects of teachers' critical thinking tendencies on organizational commitment were investigated. The sample group of the study consisted of 185 teachers who worked in a district affiliated to Denizli province. It was concluded that the critical thinking tendency variable was significantly predictive of organizational commitment, that the seniority variable was a significant predictor of the normative commitment subscale, and that the study duration was significantly predictive of continuing commitment. It was concluded that the cognitive maturity subscale had a significant effect on the continuing attachment, emotional attachment, and normative attachment dimensions and that the participation subscale was a significant predictor of the continuity attachment subscale.

Keywrods: Teachers' critical thinking, Organizational commitment, Teacher 


\section{Extended Abstract}

Purpose: In this study, the effects of teachers' critical thinking tendencies on organizational commitment were investigated. It is thought that critical thinking is neglected in our country, which is totally adherent to ideologies, ideas and persons, or wholly opposed. The question of how much involvement in an organizational criticism by a person is related to the norms within the organization, and how much parallelism or opposition it shows with the contribution they make is the main problem of this research.

Methot: This study is in the screening model.The study's universe constitutes 754 teachers who work in a province affiliated to the province of Denizli in the academic year of 2016-2017. The sample group of the study consisted of 185 teachers, determined by simple random sampling method. The UF / EMI Critical Thinking Tendency Scale was used to measure critical thinking tendencies in the research. The organizational commitment scale developed by Meyer and Allen was used to measure the organizational commitment levels of teachers. The data obtained were analyzed using descriptive statistics, correlation and multidimensional hierarchical regression analysis. In the hierarchical regressions made, the enter method and the variable selection process (Backward Selection) are used for the variable selection.

Findings: According to research findings, gender, seniority, duration of schooling, and critical thinking tendency variables accounted for about $7 \%$ of the total variance, and the critical thinking variable was significantly predictive of organizational commitment $\left(R^{2}=0.073, p<.05\right)$. The study found that the duration of study, cognitive maturity, and participation variables explained about $6 \%$ of the total variance of continuing commitment and that the duration of study, participation dimension and cognitive maturity variables were significant predictors of continuing commitment $\left(R^{2}=0.64, p<.05\right)$. The cognitive maturity dimension explained about $3 \%$ of the total variance of the emotional dependency and the cognitive maturity subscale variable was significantly predictive of emotional commitment $\left(R^{2}=0.33, p<.05\right)$. It was concluded that the cognitive maturity dimension variable explained about $9 \%$ of the total variance on the normative commitment and that the cognitive maturity dimension variable was significantly predictive of normative commitment $\left(R^{2}=0.092, p<.05\right)$.

Results and Discussion: When organizational commitment is examined from a descriptive standpoint, it is seen that organizational commitment of teachers is moderate. When the tendency to think critically is examined from a descriptive point of view, the tendency of teachers to think critically is high. It has been concluded that the variable of tendency to think critically is significantly predictive of organizational commitment. It was concluded that the age of the seniority variable was not a significant predictor of general organizational commitment but a significant predictor of the normative commitment sub-dimension. There is no impact on overall organizational commitment at school. However, it seems to be a significant predictor of continuity commitment. It is concluded that there is a positive correlation between normative attachment and emotional attachment to the cognitive maturity sub-dimension. When the effects on organizational commitment sub-dimensions are examined, it is seen that there is a significant effect on continuing commitment, emotional commitment and normative commitment dimensions. According to research findings, the tendency to think critically was achieved as a positive correlation between participation sub-dimension and emotional attachment and normative attachment. Participation sub-dimension has no significant effect on organizational commitment. However, it seems to be a significant predictor of the continuity commitment sub-dimension. Individuals with a high tendency to participate tend to be self-confident communicators who want to use their skills and use their skills to reason, solve problems and reach judgment, and explain the process of reasoning when trying to solve a problem or solve a problem. While considering the alternatives that exist in the individual's organization, he reasoned and tried to find the most appropriate alternative for him. In this context, it is possible that the participation dimension on continuing commitment, which is a type of commitment developed according to investments and alternatives, may be effective. According to research findings, the tendency to think critically, the innovative sub-dimension does not have a significant effect on organizational commitment. As a result of the research, the tendency of teachers to think critically was high. The organizational commitment is moderate. The tendency to think critically has reached the conclusion that the innovative sub-dimension is not effective on organizational commitment. In the dimension of innovation, people who tend to be innovative are "people who are hungry for information", individuals who are constantly looking for new information. For this reason, in universities where new information production is effective, it is thought that different results can be obtained if this study is applied. 


\section{Giriş}

Günümüzde çok kısa sürede fazla miktarda bilgiye ulaşabilmekteyiz. İnternet aracılığı ile, sorgulamadan, yorumlamadan ve probleme odaklanıp çözüm üretmeden bir çok bilgi hazır bir şekilde insanlara sunulmaktadır. Bilginin çabuk üretildiği, fikirlerin tartş̧ımadan tüketilip yok edildiği bir çağda, ulaşılan bilgilerin güvenilir olup olmadığı konusu, eleştirel düşünme kavramının önemini arttırmaktadır. Epstein (1999) tarafindan eleştirel düşünme, çok fazla bilginin ve insanları ikna etmeye çalışan çok fazla bireyin olduğu dünyaya karşı bir savunma mekanizması olarak tanımlanmaktadır. Eleştirel düşünme eğilimi ise, problem çözmeyi ve düşünerek karar vermeyi sağlayan tutarlı içsel motivasyon olarak tanımlanmıştır. Eleştirel düşünme eğilimi, insanların bir konuda inandıkları ve yapacakları konususunda karar vermelerini sağlayan, eleştirel düşünme becerileri için gerekli olan, dairesel bir süreçtir (Facione, Sanchez, Facione ve Gainen,1995; akt. Emir, 2013). Eleştirel düşünme becerisi, henüz doğrulanmamış iddia ve düşünceler arasında kalan bireyleri bocalamaktan kurtarır. Bireylerin bilişsel gelişimleri için gerçeğin bulunmasına yönelik sorgulama ve eleştiri, gereklidir (akt. Seferoğlu ve Akbıyık, 2006). Eleştirel düşünme, son yıllarda eğitim dünyasında üzerinde önemle durulan konulardan biridir (Braman, 1999). Eleştirel düşünme becerisi, sadece akademik alanda değil, sorun çözmeye yönelik her alanda önemlidir. 21. yüzyıl eğitimi, kendi kendine öğrenebilen, esnek, olaylara geniş bir perspektiften bakabilen, eleştirel düşünen, yaratıcı ve problem çözme becerilerine sahip bireyler yetiştirmek üzerine kuruludur (akt. Türnüklü ve Yeşildere, 2005).

Eleştirel düşünme kavramı, ilk kez 1987 yılında Delphi Araştırma Projesi'nde gündeme gelmiştir. Amerikan Felsefe Birliği tarafindan yürütülen bu proje iki yıl sürmüştür. Bu projede Kanada ile ABD'den katilan 46 eleştirel düşünme uzmanı felsefe, psikoloji, sosyoloji ve eğitim alanındaki çalışmaları incelemişler ve eleştirel düşünme kavramı ile ilgili bilgiler ve içerdiği alanlar konusunda görüş birliği sağlamışlardır (Yuva, 2011). Proje sonucunda yedi eleştirel düşünme eğilimi (meraklılık, açık fikirlilik, sistematiklik, gerçeği arama, analitiklik, olgunluk ve özgüven) tanımlanmıştr. MerakIıık, bireylerin öğrenme için istekli ve zihinsel olarak meraklı olma eğiliminin yansımasıdır. Açık fikirlilik, kişinin kendi hatalarına karşı duyarlı olmasını ve çeşitli görüşlere karşı hoşgörülü olmasını ifade eder. Sistematiklik, organize edici, planlı ve dikkatli araştırma eğilimidir. Analitiklik, sorun çıkaracak durumlara karşı dikkatli olma ve problem çözerken nesnel kanıtları kullanma eğilimidir. Gerçeği arama, iyi bilgilenme, kişinin kendi görüşlerini desteklemese bile soru sorma, dürüst ve nesnel olarak sorgulama eğilimidir. Özgüven, problemlerin çözümünde bireyin kendi akıl yürütme sürecine duyduğu güven eğilimidir. Olgunluk; problem, araştırma ve karar verme yaklaşımında bazı durumlar birden fazla seçenek sunar. Çoğu zaman kararların standartlara, konuya ve kanıtlara bağlı olması eğilimidir (Göbel, 2013). Bu raporda yorumlama, analiz, sonuç çıkarma, değerlendirme, açıklama ve öz düzenleme olmak üzere alt eleştirel düşünme becerisi tanımlanmıştı. Yorumlama; durumların, yargıların, olayların, inanışların, geleneklerin, ilkelerin, kuralların ve ölçütlerin çeşitliliğinin öneminin açıklanması ve kavranmasıdır. Analiz; durum, kavram, soru, tanımlama, yargı, inanış, görüş ve tecrübelerin arasındaki ilişkileri tanımlamadır. Sonuç çıkarma, konuyla ilgili bilgiyi dikkate alarak makul sonuçlar çıkarılması ve unsurların tanımlanmasıdır. Değerlendirme; kişinin tecrübelerinin, bakış açısının, görüşlerinin ya da inanışlarının arasındaki ilişkilerin değerlendirilmesidir. Açıklama; kavramların, ölçütlerin ve ilkelerin göz önünde bulundurularak sonuçlara bağlı olarak kanıtlar açısından doğrulanmasıdır. Öz düzenleme; bireyin bilişsel eylemlerini öz bilinçli olarak izlemesi, bu aktivitelerdeki unsurların kullanılmasıdır (Demircioğlu, 2012).

Florida Üniversitesi tarafindan yapılan araştırmada ise eleştirel düşünme eğilimi katılım, bilişsel olgunluk ve yenilikçilik olmak üzere üç alt boyutta tanımlanmıştır. Katılım eğilimi fazla olan kişiler katılım (engagement) alt boyutundadır ve iyi akıl yürütmenin zorunlu olduğu durumların beklentisi içerisindedir. Bunula birlikte akıl yürütme, problem çözme becerilerini ve yeteneklerini kullanarak ve yargıya varmak için firsat kollarlar. Bu tür bir birey bir yargıya varmaya veya bir problemi çözmeye çalışırken gerçekleştirilen akıl yürütme sürecini açıklayabilen kendinden emin bir iletişimcidir. Bilişsel olgunluk (maturity) alt boyutunda, yüksek bilişsel olgunluk düzeyine sahip olan bir kişi karar alırken önyargılarının ve kendi eğilimlerinin bilincindedir. Böyle bir birey nasıl bir düşünceye sahip olduğunun ve kendisinin kim olduğundan, deneyimlerinden ve çevresinden etkilendiğinin farkındadır. Bu kişi görüşlerine başkalarının katılmayabileceğini de dikkate alır. Bilişsel yönden belli bir olgunluğa ulaşmış insanlar; başkalarının görüşlerine saygı gösterir, eleştirilere açıktır, farklı görüşleri araştrı ve bir problemi çözerken veya yargıya varırken bunları objektif bir şekilde göz önünde bulundururlar. Yüksek bilişsel olgunluk düzeyindeki bireyler, çözümü tek olan sorunlarla çok az karşılaşacaklarını ve çoğu problemin karmaşık olduğunu bilirler. Yenilikçilik (innovativeness) alt boyutunda, yenilikçi olma eğilimi yüksek insanlar bilgi açlığı içinde olan bireyler olarak tanımlanabilir. Bu bireyler düzenli olarak yeni bilgiler edinme uğraşındadırlar. Konumlarına, mesleklerine, dünyalarına ve yaşamlarına ilişkin sürekli olarak yeni arayışlar içerisindedirler. Bu tür bireyler, entelektüel bir merak ve dürtüye sahiptir; okuyarak, sorgulayarak ve araştırarak yeni bilgilere erişmeye çalışırlar. Böyle bir birey aynı zamanda var olan inançları, doğruları ve fikirleri ile çelişik bir durumda olsa bile doğruyu bulma arzusundan vazgeçmez (Kılıç ve Şen, 2014). 
Dewey (1910; akt. Gündoğdu, 2008), eleştirel düşünme kavramını ilk tanımlayanlardan birdir. Düşünmeyi; problemin sınırlarının belirlenmesi, bir problemle karşılaşma, probleme yönelik çözümün ortaya konması ve çz̈zümün mantıksal açıklaması ve sonuçları, çözüm önerisinin kabul edilmesi veya reddedilmesi ve deneylerle kavranması olarak açıklamaktadır. Örgütler olası problemleri de içinde bulunduran yapılardır. Örgüt içinde bireyler herhangi bir problemle karşılaştklarında bu problemi çözme aşamasında zaman zaman örgütün amaç ve hedefleri ile ters düşebilmektedirler. Böyle bir durumla karşı karşıya kaldığında kişinin kendi çıkarlarını mı yoksa örgütün çıkarlarını mı koruyacağı konusunun, bireyin örgüte olan bağ|ılığı ile ilişkilendirilebilecek nitelikte bir konu olabileceği düşünülmektedir.

Seel ve A.Knight (1987), örgütün amaç ve değerlerine yönelik inanç ve kabul, örgütün bir üyesi olarak kalmak için duyulan güçlü istek ve örgütün çıkarını düşünerek yüksek performans gösterme istekliliği olmak üzere üç temel özellikle örgütsel bağlılığı açıklamışlardır. Örgüte bağlanma, işgörenin kabulü ve onun psikolojik bir sözleşmeyle işe girmesiyle başlar. Örgütün bir üyesi olarak amaçlar, hedefler ve işin zorunlulukları konusunda bilgilenmesiyle gelişir (Northcraft ve Neale, 1990; akt. Gül, 2002). O'Reilly ve Chatman (1986) örgütsel bağlılığı, örgütteki diğer çalışanlara yakın olma isteğiyle bireyin kendini ifade ettiği özdeşleşme boyutu; çalışanın örgütteki araçsal birlikteliğini açıklayan, bireysel çıkar ve amaçlara ulaşmayı hedefleyen uyum boyutu; kişisel ve örgütsel amaç ve değerlerin uygunluğu olan içselleştirme boyutunu içeren ve kişinin örgütle bütünleşme düzeyini açıklayan bir tutum olarak tanımlamaktadırlar (Güney, 2011).

Örgütsel bağlılık kavramının farklı farklı tanımlanması, bu kavramın sınıflandırılmasında da karışıklıklara yol açmaktadır. Birçok araştırmacı, farklı ölçüt ve yaklaşımları gözönüne alarak bağlııkla ilgili birbirinden farklı sınıflandırmalar yapmışlar; ancak alanyazında davranışsal bağlııı ve tutumsal bağlıık olmak üzere iki sınıflandırma türü yaygın olarak kullanılmaktadır. Örgütsel bağııı̆̆ın iki farklı şekilde sınıflandırıımasının sebebi, sosyal psikologların ve örgütsel davranışçıların konuyu farklı açılardan ele almış olmalarından kaynaklanmaktadır. Sosyal psikologlar çoğunlukla davranışsal bağ|ııı üzerinde yoğunlaşırken, örgütsel davranışçılar tutumsal bağlılık üzerinde yoğun olarak durmuşlardır (Mowday, Porter, ve Steers, 1982; akt. Gül, 2002). Tutumsal bağlııı Etzioni yaklaşımı, Kanter yaklaşımı, O'Reilly ve Chatman yaklaşımı, Allen ve Meyer yaklaşımı ve Penley ve Gould yaklaşımı olmak üzere altı grupta sınıflandırılmıştır. Davranışsal bağlıık ise Becker yaklaşımı ve Salancik yaklaşımı olmak üzere iki grupta sınıflandırılmıştır. Çoklu bağılııktaki sınıflamada ise Reichers'in yaklaşımı bulunmaktadır (Gül,2002).

Bağlılık, Kanter’a (1968; akt. İlsev, 1997) göre sosyal sistem ve kişilik olarak iki farklı sistem içerisinde ortaya çıkmaktadır. Sosyal sistemlerde bireylerin bağlılıkları sosyal kontrol, grup birliği ve sistemin devamlılığı olmak üzere üç temel alandan oluşmaktadır. Kişilik sistemi ise duygusal, normatif ve bilişsel yönelimlerden oluşmaktadır. Kanter, örgütün çalışanlardan istediği davranışların farklı bağlıık türlerini ortaya çıkardığını savunmaktadır. Çalışanlardan beklenen davranışlar, kenetlenme bağılığı, devama yönelik bağılıık ve kontrol bağ|ıı̆ının doğmasına neden olmaktadır. Devama yönelik bağıııı, çalışanın örgütün kalıcılığını sağlamaya kendisini adaması ve çalışanın örgütte kalmaya devam etmesi ile ilgilidir. Ancak burada çalışan, örgütten ayrılmanın maliyetinin, örgütte kalmanın maliyetinden daha yüksek olması nedeniyle bu davranışı sergilemektedir. Yani çalışan, kendisi için karlı olan şeyin örgütte kalmasına bağlı olduğunu anlaması durumunda örgüte bağlanmaktadır (ilısev, 1997). Kenetlenme bağlılığı, grubun kenetlenmesini kolaylaştrıcı simge ve semboller ile törenlere katılım, çalışanların önceki sosyal ilişkilerden fedakarlık etmesi gibi araçlar vasıtasıyla örgütteki sosyal ilişkilere bağlanmakta olduğunu önermektedir (Varoğlu, 1993). Kontrol bağlılı̆̆ı ise; çalışanların yönetici ve liderlerin emir ve kurallarına uyması, yani örgüt normlarına bağ|ı olmasıdır. Kontrol bağlıı̆̆ı, örgüte karşı olumlu normatif yönelimleri içermektedir. Bu nedenle kontrol bağ|ıı̆̆ı, çalışanın örgütün amaç, norm ve değerlerinin olumlu davranışlar için önemli bir rehber olduğunu kabullenmesi halinde ortaya çıkmaktadır (İnce ve Gül, 2005). Burada kişi liderin emir ve kurallarını sorgularsa bireyin kontrol bağlıı̆ı̆ının hangi yönde değişeceği sorusu akla gelmektedir. Russell’a (1963) göre sorgulama eleştirel düşünme becerilerinden ilkidir. Bu kapsamda birey eleştirel düşünme eğilimindeyse liderini ve içinde bulunduğu örgütü eleştirmesi olası bir durumdur.

Meyer ve Allen bağ|ılığı devam bağ|ılığı, normatif bağ|ılık ve duygusal bağ|ılık olmak üzere üç alt boyutta ele almışlardır. Duygusal bağ|ıık, çalışanların örgütle özdeşleşmelerine ve duygusal bir bağ geliştirmelerine yönelik bağ|lıktır. Çalışanlar örgütte kendi istedikleri için kalmayı sürdürürler, kendilerini örgüt içinde ailenin bir parçası gibi görür, başka bir örgütte daha iyi iş olanakları olsa bile, bu örgütten duygusal nedenlerle ayrılmak istemezler (Allen ve Meyer, 1990; Güney, 2011). Devam bağılığı ile örgüte bağlı olan işgörenlerin örgütten ayrılmanın maliyetinin yüksek olacağını düşünüp örgüt üyeliğine devam etmelerini sağlayan bir bağlılık türüdür. Ayrıca maliyete göre çalışan yüksek ödül alıyorsa örgüte bağılığı da o oranda yüksek olur. Devam bağlılı̆ında, örgüte yapılan yatıııların boyutu ve sayısı ile başka alternatiflerin algılanan azlığı iki önemli faktördür. Eğer çalışanın örgüte yaptığı yatııı fazlaysa işinden ayrılmayı istememektedir (Allen ve Meyer, 1990; Güney, 2011). Normatif bağlılıkta ise çalışanlar, çalışthğı kuruma karşı sorumlulukları ve 
yükümlülükleri olduğuna inanarak, örgütte kalmayı kendileri için bir zorunluluk olarak görürler. Normatif bağlığı yüksek olan işgörenler bireysel çıkarlardan çok ahlaki değerlere önem veren davranış sergilerler. Normatif bağlılık, bireyin önceki tecrübelerinden etkilenmektedir, örneğin eğitim, staj gibi kişinin kendini örgüte borçlu hissedeceği nedenlerden kaynaklanabilir. Normatif bağlılığa ayrıca kültürel birikimler, sosyal baskılar, statü, kişinin karakter yapısı ve sorumluluk duygusu gibi faktörler de etki eder (Allen ve Meyer, 1990; ak. Güney, 2011). Russell'a (1963) göre eleştirel düşünme becerisi faktörlerinden biri olan yargılama faktörü bazı standart, norm ve görüş birliklerinin değerlendirilmesini kapsar (Wolf, King ve Hulk, 1968). Bu açıdan bakıldığında yargılama eğilimi olan bireyin içinde bulunduğu normlara bakış açısının normatif bağlılığa ne düzeyde etki edebileceği sorusu akla gelmektedir.

Allen ve Meyer (1990) devam bağ|ılığını Becker'in (1960) yan bahisler teorisinden esinlenerek geliştirmişlerdir. Becker (1960) örgütsel bağ|ılığı "kişinin örgütte çalıştı̆̆ı süre içinde geçirdiği zaman, sarfettiği emek, çaba ve edindiği para ve statü gibi değerleri örgütten ayrıldığı zaman bütün yaptıklarının boşa gideceği ve kaybedeceği korkusu sonucu oluşan bağlııktır" şeklinde tanımlamıştır. Becker'e göre birey, örgüte karşı duygusal olarak bir bağlıık geliştirmez, bağlanmadığı takdirde kaybedeceklerini dikkate aldığı için örgüte bağlanır ve örgütte çalışmayı sürdürür (akt. Gökmen, 1999). Becker'ın yan bahisler olarak tanımladığı teoride, kişinin örgüte olan bağlılığının artması aşamasında, Bloom'un üst düzey eleştirel düşünme yetisinin oluşması için düşünmenin düzeyleri arasında tanımladığı değerlendirme, kurgulama, genelleme, yordama, yargılama, speküle etme, tahminleri ve varsayımlar içeren değerlendirme sürecini kullandığı görülmektedir. Bu kapsamda eleştirel düşünme eğilimi ile örgütsel bağlılık kavramlarının birbiriyle ilişkili olabileceği düşünülmektedir.

Literatüre bakıldığında eleştirel düşünme eğiliminin örgütsel bağılığı yordaması ile ilgili bir çalışmaya rastlanamamıştır. Örgütsel bağlılığın çoğunlukla iş doyumu, liderlik, örgütsel adalet, motivasyon ve örgütsel güven gibi konularla birlikte çalışıldığı görülmektedir (Bülbül, 2016; Özkan, 2017; Tok, 2004, 2013; Vural, 2016; Zeynel, 2014). Eleştirel düşünme eğiliminin ise sınıf yönetimi, yaratıcı düşünme, duygusal zeka ve karar verme stratejileri gibi konularla birlikte çalışıldığı görülmektedir (Varoğlu, 2014; Toyran, 2015; Korkmaz,2009; Küçük, 2007; Tuncer, 2013; Bayat,2014). Bu araştırmada öğretmenlerin eleştirel düşünme eğilimlerinin, örgütsel bağlılık düzeylerine etkisi araştıılımıştr. İdeolojilere, fikirlere ve kişilere tamamen bağlılık ya da tamamen karşıtlığın benimsendiği ülkemizde eleştirel düşünmenin ihmal edilen bir alan olduğu düşünülmektedir. Kişilerin eleştirdiği bir örgüte ne düzeyde bağılık gösterdikleri örgüt içindeki normlara ne kadar dahil oldukları, örgüte sundukları katkı ile ne düzeyde paralellik ya da karşıtlık gösterdiği konusu bu araştrmanın temel problemidir.

Öğretmenlerin eleştirel düşünme eğilimlerinin örgütsel bağlılık üzerindeki etkisini ortaya koymayı amaçlayan bu çalışmada aşağıdaki sorulara yanıt aranmıştır:

- Öğretmenlerin eleştirel düşünme eğilimleri hangi düzeydedir?

- Öğretmenlerin örgütsel bağ|ılıkları hangi düzeydedir?

- Öğretmenlerin cinsiyeti, kıdemi ve bulundukları okulda çalışma süresi değişkenleri ile örgütsel bağ|ılık düzeyi ve alt boyutları arasında anlamlı bir ilişki var mıdır?

- Öğretmenlerin cinsiyeti, kıdemi ve bulundukları okulda çalışma süresi değişkenleri ile öğretmenlerin eleştirel düşünme eğilimleri ve alt boyutları arasında anlamlı bir ilişki var mıdır?

- Öğretmenlerin eleştirel düşünme eğilimleri ile örgütlerine olan bağlılıkları arasında anlamlı bir ilişki var mıdır?

- Eleştirel düşünmenin alt boyutları, örgütsel bağııı̆̆ın alt boyutlarının anlamlı bir yordayıcısı mıdır?

\section{Yöntem}

\section{Araştırmanın Modeli}

Çalışmada, tarama modellerinden biri olan "ilişkisel tarama" modeli kullanılmıştr. Tarama modelleri, geçmişte ya da halen var olan bir durumu, var olduğu şekliyle betimlemeyi amaçlayan araştırma yaklaşımlarıdır (Karasar, 2005). Eğer, araştırma çok sayıda obje veya insana ilişkin bazı betimlemelerde bulunmayı amaçlıyorsa tarama modeli en uygun modellerden biridir (Balcı, 1995). Iliş̧kisel tarama modeli ise iki ve daha çok sayıdaki değişken arasında (birlikte değişim) varlığını ve veya ölçüsünü (derecesini) saptamayı amaçlayan araştırma modelidir (Karasar, 2005). 


\section{Evren ve Örneklem}

Tablo 1. Katılımcıların Demografik Özellikleri

\begin{tabular}{lccc}
\hline & & $F$ & $\%$ \\
\hline \multirow{2}{*}{ Cinsiyet } & Kadın & 93 & 50.3 \\
& Erkek & 92 & 49.7 \\
\hline \multirow{3}{*}{ Kıdem Yılı } & $1-5$ & 37 & 20.0 \\
& $6-10$ & 44 & 23.8 \\
& $11-15$ & 26 & 14.1 \\
& $16-20$ & 20 & 10.8 \\
Okulda Çalışma Süresi & $21+$ & 58 & 31.4 \\
& $1-5$ & 118 & 63.8 \\
& $6-10$ & 28 & 15.1 \\
& $11-15$ & 8 & 4.3 \\
& $16-20$ & 14 & 7.6 \\
\hline
\end{tabular}

Araştırmanın evrenini 2016-2017 eğitim-öğretim yılında Denizli iline bağlı bir ilçede görev yapan 754 öğretmen oluşturmaktadır. Araştırmanın örneklem grubu, basit tesadüfi örnekleme yöntemi ile belirlenen, 185 öğretmenden oluşmaktadır. Basit tesadüfi örneklemede evreni oluşturan her elemanın örneğe girme şansı eşittir. Dolayısıyla hesaplamalarda da her elemana verilecek ağırlık aynıdır (Arıkan, 2004).

\section{Veri toplama Araçları}

Literatüre baktığımızda farklı boyutları içeren eleştirel düşünme eğilimi ölçekleri görülmektedir. Cornell Eleştirel Düşünme Testi Z Formu ve Watson-Glaser Eleştirel Düşünme Değerlendirilmesi Testleri değerlendirici beceri ve analitik beceri olmak üzere iki boyuttan oluşmaktadır. Williams (2002), testlerin Delphi Modeli'ne göre tasarlandığını ifade etmektedir. Kaliforniya Eleştirel Düşünme Becerileri Testi ve Kaliforniya Eleştirel Düşünme Eğilimleri Envanteri ise Delphi Modeli raporuna göre hazırlanmıştır ve daha fazla boyut içermektedir (Facione ve Facione, 1998). Türkiye'de yapılan çalışmalarda, eleştirel düşünme eğilim düzeyini belirlemede çoğunlukla Kökdemir (2003) tarafindan lisans düzeyinde Türkçeye uyarlaması yapılan Kaliforniya Eleştirel Düşünme Eğilimi Ölçeği'nin (CCTDI) kullanıldığı görülmektedir (Şen, 2016; Açıkgöz, 2015; Varoğlu,2014; Kasımoğlu, 2013; Kızıltaş, 2011; Hazer, 2011; Küçük, 2007). Bu çalışmada ise Kılıç ve Şen (2014) tarafindan Türkçe'ye uyarlanan UF/EMI Eleştirel Düşünme Eğilim Ölçeği (University of Florida Engagement, Maturity and Innovativeness Critical Thinking Disposition Instrument) kullanılmıştir. UF/EMI' de bulunan Maturity, Engagement ve Innovativeness, uzmanların görüşleri de dikkate alınarak, Türkçe'ye "Bilişsel Olgunluk, Katılım ve Yenilikçilik" olarak çevrilmiştir (Kılıç ve Şen, 2014). Ölçekte toplam 11 madde (2-3-5-7-8-9-13-16-17-18-21) katılım boyutunu, yedi madde (1-12-15-19-23-24-25) bilişsel olgunluk boyutunu, yedi madde (4-6-10-11-14-20-22) yenilikçilik boyutunu ölçmek için kullanılmaktadır. Bu araştırma sonucunda ölçeğin Cronbach alfa iç tutarlılık katsayısı 0.93 olarak tespit edilmiştir.

Türkiye'de örgütsel bağlılık ile ilgili yapılan çalışmalara bakıldığında çoğunlukla Allen ve Meyer (1990) tarafindan geliştirilen ölçeğin kullanıldığı görülmektedir (Toksöz, 2015; Kalkavan, 2014; Zeynel, 2014; Atak,2009; Boylu, Pelit ve Güçer, 2007; Durna ve Eren, 2005; Tok, 2004). Bu çalışmada da Meyer ve Allen tarafindan geliştirilen duygusal bağlıık, normatif bağlılık ve devam bağlıığı olmak üzere üç alt boyuttan oluşan Örgütsel Bağlılık Ölçeği kullanılmıştrr. Ölçekte toplam alt madde (1-2-3-4-5-6) duygusal bağlılık boyutunu ölçmek için, alt madde (7-8-9-10-11-12) devam bağılığı boyutunu ölçmek için ve beş madde(13-14-15-16-17) normatif bağlıık boyutunu ölçmek için kullanılmıştır. Bu araştırma sonucunda ölçeğin Cronbach alfa iç tutarlılık katsayısı .84 olarak tespit edilmiştir.

Ölçeklerdeki her bir madde için 5'li Likert tipi derecelendirme ölçeği kullanılmıştr. Olumsuz maddelerde (Örgütsel bağlıık ölçeği; 7, 8, 9, 10) derecelendirme aşağıdaki şekildedir.

- $1.00-1.80$ Kesinlikle Katlıyorum

- 1.81 - 2.60 Katllyyorum

- $2.61-3.40 \mathrm{Az}$ katilıyorum

- $3.41-4.20$ Katilmıyorum

- 4.21 - 5.00 Kesinlikle Katilmıyorum 
- Olumsuz maddelerde alınacak en düşük puan aralığı "1.00 - 1.80" ve en yüksek puan aralığı ise "4.21-5.00"dir.

Olumlu maddelerde ise derecelendirme aşağıdaki şekildedir.

- 1.00 - 1.80 Kesinlikle Katılmıyorum

- 1.81 - 2.60 Katılmıyorum

- $2.61-3.40 \mathrm{Az}$ katlıyorum

- 3.41 - 4.20 Kathlıyorum

- 4.21 - 5.00 Kesinlikle Katlıyorum

Olumlu maddelerde alınacak en yüksek puan aralığı (4.21-5.00) "Kesinlikle Katılıyorum" ifadesidir. En düşük puan aralığı (1.00-1.80) ise "Kesinlikle Katılmıyorum" ifadesine karşılık gelmektedir.

\section{Verilerin analizi}

Elde edilen veriler, betimsel istatistik, korelasyon ve çok yönlü hiyerarşik regresyon analizi kullanılarak incelenmiştir. Eleştirel düşünme eğilimi alt boyutları ile örgütsel bağılık alt boyutları arasında anlamlı bir ilişkinin olup olmadığı Pearson Korelasyon katsayısı ile sınanmıştır. Ayrıca cinsiyet, kıdem yılı, okulda çalışma süresi ve eleştirel düşünme eğilimi değerlerinin örgütsel bağlıı̆̆ı ne derecede yordadığını belirlemek için ise çoklu regresyon analizi kullanılmıştır. Çoklu regresyon analizi, birden fazla bağımsı değişkenin bir bağımlı değişkeni açıklaması için kurulan modelleri test etmek ve bağımsız değişkenlerin modele olan birebir katkılarını sırasıyla inceleyebilmek için kullanılmaktadır. Bir başka deyişle iki veya daha fazla değişken arasında herhangi bir ilişki olup olmadığı; bu ilişkinin derecesini değerlendirmek üzere kullanılır. Bir grup bağımsız değişkenin bağımlı değişken hakkında ne kadar bilgi verdiği değerlendirildikten sonra, regresyon fonksiyonuna başka bir grup bağımsız değişken eklemek suretiyle bağımlı değişken hakkında daha fazla bilgi edinilip edinilmediği istatistiksel olarak değerlendirilir (Durmuş, B., Yurtkoru, E. S. ve Çinko, M.,2013).

Bu çalışmada yapılan hiyerarşik regresyonlarda değişken seçimi için enter metodu ve değişken eleme işlemi (Backward Selection) kullanılmıştır. Araştırmacı, enter metotunda öncelikli olarak modelin oluşmasında etkili olan bağımsız değişkenleri belirtir ve sonra oluşturulan modelin bağımlı değişkenleri tahmin etme başarısını değerlendirir. Bu model, bir bağımsız değişkenin diğer bağımsız değişkenden daha önemli olduğu durumlarda kullanılır. Değiş̧kenler birebir modele eklendiği gibi, modele olan katkıları da birebir değerlendirilir. Eklenen değişkenin modeli tahmin etme gücünü arttırmadığı durumlarda değişkenin modelden çıkarılması uygun olabilir. Değişken eleme işleminde ise tüm değişkenler modele dahil edilir. En zayıf bağımsız değişken modelden çıkarılarak regresyon yeniden hesaplanır ve bu durumda model önemli ölçüde güç yitimine uğruyorsa, bağımsız değişken modele tekrar eklenir. Eğer, güçsüzleşme önemli derecede değilse bağımsız değişken modelden çıkarılır. Sadece faydalı bağımsız değişkenler modelde kalıncaya kadar bu süreç devam eder (Kalaycı, 2006).

\section{Bulgular}

Öğretmenlerin eleştirel düşünme eğilimlerinin örgütsel bağlıık üzerindeki etkisini ortaya koymayı amaçlayan çalışmanın bu bölümünde alt problemler doğrultusunda bulgulara yer verilmiştir.

\section{1. Örgütsel Bağlılık ve Eleştirel Düşünme Eğilimine ilişkin Betimsel Bulgular}

Çalışmanın bu alt bölümünde birinci ve ikinci alt problemlerde bulunan öğretmenlerin eleştirel düşünme eğilimleri ve örgütsel bağlıııklarının hangi düzeyde olduğuna yönelik görüşleri ile ilgili bulgular yer almaktadır.

Örgütsel bağlıık ölçeği uygulama sonuçlarına göre ulaşılan (Kolmogorov Smirnov Z=,95; p>.05) örgütsel bağ|lık puanlarının ve eleştirel düşünme eğilimi ölçeği uygulama sonuçlarına göre ulaşılan (Kolmogorov Smirnov Z=,77; p>.05) eleştirel düşünme eğilimi puanlarının normal dağıııma uygun olduğu görülmüştür.

Tablo 2. Örgütsel Bağlılık ve Alt Boyutlarına ilişkin Betimsel Değerler

\begin{tabular}{lccc}
\hline & $\mathrm{N}$ & $\overline{\mathrm{x}}$ & $\mathrm{SS}$ \\
\hline Örgütsel Bağ|ıık & 185 & 3.34 & .68 \\
Duygusal Bağ|ıık & 185 & 3.71 & 1.12 \\
Devam Bağ|ılık & 185 & 3.07 & .85 \\
Normatif Bağ|ılık & 185 & 3.23 & .96 \\
\hline
\end{tabular}

Tablo 2'de örgütsel bağlılık betimsel olarak incelendiğinde maddelere verilen cevapların çoğunlukla "kısmen katılı- 
yorum" düzeyinde olduğu görülmektedir. Duygusal bağ|ılık alt boyutundaki maddelere verilen cevapların ortalamasının $\bar{x}=3.71$ olduğu görülmekte, bir başka deyişle bu bulgu katılımcıların çoğunlukla 'katılıyorum' cevabını verdiğini göstermektedir. Devam bağ|ılığı alt boyutundaki maddelere verilen cevapların ortalamasının $\bar{x}=3.07$; normatif bağlılık alt boyutundaki maddelere verilen cevapların ortalamasının ise $\bar{x}=3.23$ olduğu, her iki bağlılık boyutundaki maddelere de katılımcıların çoğunlukla "kısmen katıldıkları" görülmektedir.

Tablo 3. Eleştirel Düşünme Eğilimi ve Alt Boyutlarına iliş̧in Betimsel Değerler

\begin{tabular}{lccc}
\hline & $\mathrm{N}$ & $\overline{\mathrm{x}}$ & $\mathrm{SS}$ \\
\hline Eleştirel Düşünme Eğilimi & 185 & 4.12 & .47 \\
Bilişsel Olgunluk & 185 & 4.07 & .54 \\
Katlım & 185 & 4.19 & .48 \\
Yenilikçi & 185 & 4.13 & .48 \\
\hline
\end{tabular}

Tablo 3'te eleştirel düşünme eğilimi betimsel açıdan incelendiğinde maddelere verilen cevapların çoğunlukla "kattlıyorum" şeklinde olduğu görülmektedir. Bilişsel olgunluk alt boyutundaki maddelere verilen cevapların ortalamasının $\bar{x}=4.12$ olduğu; bu boyutta katılımcıların çoğunlukla 'katılıyorum' cevabını verdiği anlaşılmaktadır. Katılım alt boyutundaki maddelere verilen cevapların ortalamasının $\bar{x}=4.07$ olduğu; bu alt boyutta katlımcıların çoğunlukla 'kathlıyorum' cevabını verdiği; yenilikçi alt boyutundaki maddelere verilen cevapların ortalamasının $\bar{x}=4.13$ olduğu; katılımcların çoğunlukla bu boyuttaki maddelere de 'kathlıyorum' cevabını verdikleri görülmektedir.

\section{2. Öğretmenlerin Kişisel Özellikleri Doğrultusunda Eleştirel Düşünme Eğilimlerine Yönelik Bulgular}

Öğretmenlerin cinsiyetlerine göre eleştirel düşünme eğilimlerine yönelik görüşleri ortaya koymak amacıyla yapılan analiz sonucunda cinsiyet değişkeninin örgütsel bağlılık ve alt boyutları üzerinde etkili olmadığı görülmüştür $(p>0,05)$. Bir başka anlatımla, öğretmenlerin kadın ya da erkek olmaları, onların eleştirel düşünme eğilimlerine yönelik görüşlerinde istatistiksel olarak anlamlı bir farka yol açmamaktadır (Tablo 4).

Tablo 4. Öğretmenlerin Cinsiyetlerine Göre Eleştirel Düşünme Eğilimlerine ve Alt Boyutlarına İlişkin Görüşleri

\begin{tabular}{|c|c|c|c|c|c|c|c|c|c|c|}
\hline & & \multirow[t]{2}{*}{$\mathrm{n}$} & \multicolumn{2}{|c|}{ Eleştirel Düşünme Eğilimi } & \multicolumn{2}{|c|}{ Katılım } & \multicolumn{2}{|c|}{ Bilişsel olgunluk } & \multicolumn{2}{|c|}{ Yenilikçi } \\
\hline & & & $\mathrm{t}$ & $\mathrm{p}$ & $\mathrm{t}$ & $\mathrm{p}$ & $\mathrm{t}$ & $p$ & $\mathrm{t}$ & $\mathrm{p}$ \\
\hline Cinsiyet & $\begin{array}{l}\text { Erkek } \\
\text { Kadın }\end{array}$ & $\begin{array}{l}93 \\
92\end{array}$ & .009 & .927 & .110 & .740 & .076 & .783 & .075 & .785 \\
\hline
\end{tabular}

Öğretmenlerin kıdem yılı ve okulda çalışma süresi değişkenleri ile eleştirel düşünme ve alt boyutları arasında anlamlı bir iliş̧i olup olmadığı Tablo 5'te yer almaktadır. ANOVA tablosundan kıdem yılı değişkeni ile eleştirel düşünme $(F=1.43$, $p>.005)$, bilişsel olgunluk alt boyutu $(F=2.43, p>.005)$, yenilikçi alt boyutu $(F=2.26, p>.005)$ ve kathlım alt boyutu $(F=.65$, $p>$.005) arasında anlamlı bir ilişkinin olmadığı görülmüştür. Yine aynı şekilde öğretmenlerin okulda çalışma süresi ile eleştirel düşünme ( $F=.740, p>.005)$, bilişsel olgunluk alt boyutu ( $F=1.10, p>.005)$, yenilikçi alt boyutu $(F=.683, p>.005)$ ve katılım alt boyutu ( $F=.727, p>.005$ ) arasında anlamlı bir ilişkinin olmadığı görülmüştür (Tablo 5).

Tablo 5. Öğretmenlerin Kıdem Yılı ve Okulda Çalışma Süresine Göre Eleştirel Düşünme ve Alt Boyutlarına ilişkin Görüşleri

\begin{tabular}{|c|c|c|c|c|c|c|c|c|c|c|}
\hline & & \multirow[t]{2}{*}{$\mathrm{n}$} & \multicolumn{2}{|c|}{ Eleştirel Düşünme Eğilimi } & \multicolumn{2}{|c|}{ Yenilikçi } & \multicolumn{2}{|c|}{ Bilişsel } & \multicolumn{2}{|c|}{ Katılım } \\
\hline & & & $\mathrm{F}$ & $\mathrm{p}$ & $\mathrm{F}$ & $p$ & $\mathrm{~F}$ & $p$ & $\mathrm{~F}$ & $p$ \\
\hline \multirow{5}{*}{ Kıdem Yılı } & $1-5$ & 37 & & & & & & & & \\
\hline & $6-10$ & 44 & & & & & & & & \\
\hline & $11-15$ & 26 & 1.43 & .22 & 2.26 & .064 & 2.43 & .051 & .65 & .62 \\
\hline & $16-20$ & 20 & & & & & & & & \\
\hline & $20+$ & 58 & & & & & & & & \\
\hline \multirow{5}{*}{$\begin{array}{l}\text { Okulda Çalışma } \\
\text { Süresi }\end{array}$} & $1-5$ & 118 & & & & & & & & \\
\hline & $6-10$ & 28 & & & & & & & & \\
\hline & $11-15$ & 8 & .740 & .566 & .683 & .604 & 1.10 & .360 & .727 & .574 \\
\hline & $16-20$ & 14 & & & & & & & & \\
\hline & $20+$ & 17 & & & & & & & & \\
\hline
\end{tabular}




\section{3. Öğretmenlerin Kişisel Özellikleri Doğrultusunda Örgütsel Bağlılık Düzeyine Yönelik Görüşleri}

Öğretmenlerin cinsiyetlerine göre yapılan t-testi sonucunda cinsiyet değişkeni ile örgütsel bağlılık ve alt boyutları arasında anlamlı bir ilişkinin olmadığı görülmüştür $(p>0,05)$. Diğer bir deyişle öğretmenlerin görüşleri, onların kadın ya da erkek olmalarına göre farklılaşmamaktadır (Tablo 6).

Tablo 6. Öğretmenlerin Cinsiyetlerine Göre Örgütsel Bağlılık ve Alt Boyutlarına Illişkin Görüşleri

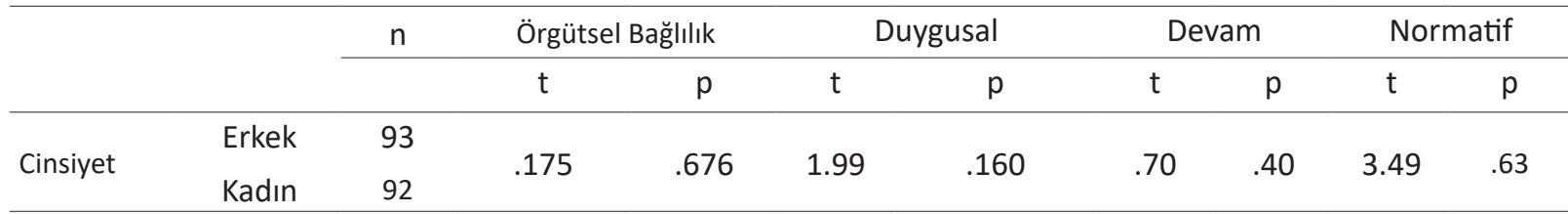

Öğretmenlerin kıdem yılı ve okulda çalışma süresi değişkenleri ile örgütsel bağlılık ve alt boyutları arasında nasıl bir ilişki olduğu Tablo 7'de yer almaktadır. ANOVA tablosundan kıdem yılı değişkeni ile örgütsel bağlılık $(F=3.59, p<.005)$, devam bağ|ı Iı̆ı $(F=2.52, p<.005)$ ve normatif bağlılık $(F=4.44, p<.005)$ arasında anlamlı bir ilişkinin olmadığı olduğu anlaşılmaktadır. Yapılan Tukey testi sonucu kıdem yılı 1-5 yıl olanların örgütsel bağılık düzeylerinin 6-10 ve 16-20 yıl arasında olanlardan daha fazla olduğu, kıdem yılı 1-5 yıl olanların devam bağlılık düzeylerinin 6-10 arasında olanlardan daha fazla olduğu, kıdem yılı 1-5 yıl olanların normatif bağılık düzeylerinin ise 6-10, 11-15, 16-20 ve 20 yıl ve üzeri kıdemi olanlardan daha fazla olduğu tespit edilmiştir (Tablo 7). Yine aynı tabloda görüldüğü gibi okulda çalışma süresi değişkeni ile devam bağılığı $(F=2.58, p<.005)$ arasında anlamlı bir ilişkinin olduğu görülmüştür. Yapılan Tukey testi sonucu kıdem yılı 1-5 yıl olanların devam bağlılık düzeylerinin 20 ve üstü yıl arasında olanlardan daha fazla olduğu görülmüştür.

Tablo 7. Öğretmenlerin Kıdem Yılı ve Okulda Çalışma Süresine Göre Örgütsel Bağlıık ve Alt Boyutlarına ilişkin Görüşleri

\begin{tabular}{|c|c|c|c|c|c|c|c|c|c|c|}
\hline & & . & Örgü & lilık & Duy & & & & & atif \\
\hline & & $\mathrm{n}$ & $\mathrm{F}$ & $p$ & $\mathrm{~F}$ & $p$ & $\mathrm{~F}$ & $p$ & $\mathrm{~F}$ & $p$ \\
\hline & $1-5$ & 37 & & & & & & & & \\
\hline & $6-10$ & 44 & & & & & & & & \\
\hline Kıdem Yılı & $11-15$ & 26 & 3.59 & .008 & .913 & .458 & 2.52 & .043 & 4.44 & .002 \\
\hline & $16-20$ & 20 & & & & & & & & \\
\hline & $20+$ & 58 & & & & & & & & \\
\hline & $1-5$ & 118 & & & & & & & & \\
\hline & $6-10$ & 28 & & & & & & & & \\
\hline Ukulda Çalışma & $11-15$ & 8 & 1.25 & .29 & .57 & .68 & 2.58 & .039 & .827 & .510 \\
\hline & $16-20$ & 14 & & & & & & & & \\
\hline & $20+$ & 17 & & & & & & & & \\
\hline
\end{tabular}

\section{4. Öğretmenlerin Eleştirel Düşünme Eğilimleri İle Örgütlerine Olan Bağılııkları Arasındaki illişkiye Yönelik Korelas-} yon Sonuçları

Öğretmenlerin eleştirel düşünme eğilimleri ile örgütlerine olan bağlııkları arasında anlamlı bir ilişkinin olup olmadığına yönelik ortalama skorlar, standart sapmalar ve değişkenler arası korelasyon değerleri Tablo 8'de sunulmuştur. Faktör grupları arasındaki korelasyona bakıldığında değişkenler arasında, 0.01 ve 0.05 anlamlılık seviyesinde ilişkiler olduğu görülmektedir. Tablo 8'deki korelasyon analizi sonuçlarına göre en yüksek korelasyon ilişkisi 0.856 ile katılım ile yenilikçilik arasında gerçekleşmiştir. Duygusal bağılık ile normatif bağılık, katılım, bilişsel olgunluk ve yenilikçi alt boyutları arasında anlamlı ilişkiler saptanmıştı. Bununla beraber devam bağlılığı ile diğer faktörler arasında anlamlı bir ilişkiye rastlanılamamıştr. 
Tablo 8. Araştırmanın Ana Değişkenleri Arasındaki Basit Korelâsyon Katsayıları, Ortalama Ve Standart Sapma Değerleri

\begin{tabular}{lcccccccc}
\hline & Ort. & S.S. & 1 & 2 & 3 & 4 & 5 & 6 \\
\hline 1. Duygusal Bağ|ıık & 3.71 & 1.13 & 1 & & & & & \\
2. Devam Bağ|ı̆ığı & 2.76 & .81 & .138 & 1 & & & & \\
3. Normatif Bağııık & 3.24 & .96 & $.415^{* *}$ & .068 & 1 & & & \\
4. Katılım Boyutu & 4.07 & .54 & $.174^{*}$ & .109 & $.218^{* *}$ & 1 & & \\
5. Bilişsel Olgunluk Boyutu & 4.19 & .48 & $.180^{*}$ & .001 & $.304^{* *}$ & $.738^{* *}$ & 1 & \\
6. Yenilikçi Boyutu & 4.13 & .48 & $.175^{*}$ & -.071 & $.211^{* *}$ & $.856^{* *}$ & $.742^{* *}$ & 1 \\
\hline
\end{tabular}

$* p<.05 * * p<.01$

\section{Eleştirel Düşünme Alt Boyutlarının Örgütsel Bağlııı̆ın Alt Boyutlarını Yordama Düzeyine Ilişkin Bulgular}

\section{Hiyerarşik Çoklu Regresyon Analizi Sonuçları}

Yapılan hiyerarşik regresyonlarda değişken seçimi için enter metodu ve değişken eleme işlemi (Backward Selection) kullanılmıştı. Analizler sonunda elde edilen determinasyon katsayıları $\left(R^{2}\right)$ karşılaştrılarak demografik değişkenlerin ve eleştirel düşünme eğilimi alt boyutlarının örgütsel bağlılık hakkında bilgi verip vermediği değerlendirilmiştir. R2 değeri regresyon eşitliğinin açıklama gücünü ifade eder. Bu değer 0 ile 1 arasında değişir ve yüksek R2 değeri yüksek açıklama oranına işaret etmektedir (Hair, Black, Babin, Rolph, 2010; akt. Kayanak, Karadeniz ve Durmaz, 2016). En yüksek R2 değeri 0.073 bulunmuştur. Bu kapsamda algılanan fayda değişkeninin açıklanma oranı \% 7'de kalmıştır.

Bağımsız ve bağımlı değişkenler arasında korelasyon olmaması ve hata terimleri arasında korelasyon olmaması regresyonun önemli varsayımlarındandır. Hata terimleri arasında korelasyon olup, olmadı̆̆ını belirlemek için Durbin Watson istatistiği kullanılmıştır. 0 ile 4 arasında bulunan bu istatiksel değerin 2 civarında çıkması, korelasyon olmadığı şeklinde yorumlanır. 4'e yakın değerler yüksek negatif korelasyonu, 0'a yakın değerler yüksek pozitif korelasyonu belirtir. Araştirmada yapılan istatistik sonucu Durbin Watson istatistik değeri 2.156'dir. Bu durumda hata terimleri arasında korelasyon olmadığı sonucuna ulaşılmıştır. Regresyon modelinde bağımlı ve bağımsız değişkenler arasında yüksek korelasyon olmaması gerekmektedir. VIF değeri, bu sorunun varlığının saptanması için kullanılır. VIF değeri 5 ve yukarı olduğu durumlarda, değişkenin diğer regresyon modeli değişkenleri ile yüksek korelasyona sahip olduğu sonucuna ulaşılır ve modelden çıkarılması gerekir (Hair vd., 2010; Kayanak,vd., 2016). Tablo 9'da VIF değerinin 1 ile 5 arasında olduğu görülmektedir. 5 ve daha yüksek çıkmadığı için bağımsız değişkenler arasında korelasyon olmadığı ve değişkenlerin modelde kalmasının uygun olacağı şeklinde yorumlanabilir.

Model 1'de, cinsiyet, kıdem yılı, okulda çalışma süresi ve eleştirel düşünme eğilimi değişkenleri toplam varyansın yaklaşık $\%$ 7'sini açıklamaktadır $\left(R^{2}=0.073, p<.05\right)$. Yapılan analiz sonucunda $F=3.539, p=.008$ değerlerine ulaşılmıştr. Bu durumda modelin $p<.05$ düzeyinde anlamlı olduğu bulgusuna ulaşılmıştır. Standardize edilmiş regresyon katsayılarına ( $\beta$ ) göre, model 1'de bulunan yordayıcı bağımsız değişkenlerin örgütsel bağlılık üzerindeki göreceli önem sıralaması; eleştirel düşünme eğilimi, kıdem yılı, cinsiyet ve okulda çalışma süresidir. Regresyon katsayılarının anlamlılı̆ına ilişkin yapılan analiz sonuçlarına göre, eleştirel düşünme değişkeninin örgütsel bağlılık üzerinde anlamlı yordayıcı olduğu görülmektedir ( $p<.05$ ) (Tablo 9).

Tablo 9. Hiyerarşik Çoklu Regresyon Analizi Sonuçları

\begin{tabular}{|c|c|c|c|c|c|c|}
\hline Model & Değişkenler & $\beta$ & $\mathrm{t}$ & $\mathrm{p}$ & VIF & $R^{2}$ \\
\hline \multirow{4}{*}{1} & Cinsiyet & ,026 & 315 & ,753 & ,026 & \\
\hline & Kıdem Yılı &,- 101 & $-1,069$ & ,286 &,- 101 & \\
\hline & Okulda Çalışma Süresi & ,018 &,- 212 & ,832 &,- 018 & \\
\hline & Eleştirel Düşünme Eğilimi & 234 & 3,214 & ,002 & 234 & .073 \\
\hline
\end{tabular}

Eleştirel düşünme alt boyutlarının örgütsel bağlılık alt boyutlarını yordama düzeyine ilişkin bulgulara, hiyerarşik regresyon değişken eleme metodu kullanılarak ulaşılmıştır. Araştırma bulgularına göre devam bağılığına ilişkin Durbin Watson istatistik değeri 2.094'dür. Yani 2 civarındadır ve hata terimleri arasında korelasyon olmadığı sonucuna ulaşılmıştı. Tablo 10'da VIF değerlerinin 1 ile 5 arasında olduğu görülmektedir. 5 ve üzeri bir değer bulunmadığı için bağımsız değişkenler arasında korelasyon olmadığı ve değişkenlerin modelde kalmasının uygun olacağı şeklinde yorumlanabilir.

Mode I'de, cinsiyet, kıdem yılı, okulda çalışma süresi, bilişsel olgunluk, katılım ve yenilikçi değişkenleri toplam varyansın yaklaşık \% 7'sini açıklamaktadır $\left(R^{2}=0.69, p<.05\right)$. Yapılan analiz sonucunda $F=2.213, p=.044$ değerlerine ula- 
şılmıştır. Bu durumda modelin $p<.05$ düzeyinde anlamlı olduğu bulgusuna ulaşılmıştır. Standartlaştıılmış regresyon katsayılarına ( $\beta$ ) göre, model 1'de bulunan yordayıcı bağımsız değişkenlerin devam bağlıığı üzerindeki göreceli önem sıralaması; katlım boyutu, bilişsel olgunluk boyutu, okulda çalışma süresi, kıdem yılı, yenilikçi boyutu ve cinsiyettir. Regrasyon katsayılarının anlamlıı̆ı̆na ilişkin yapılan analiz sonuçlarına göre, katılım boyutu ve bilişsel olgunluk değişkenlerinin devam bağlılığı üzerinde anlamlı yordayıcılar olduğu görülmektedir ( $p<.05$ ) (Tablo 10).

Model 2'de, cinsiyet, kıdem yılı, okulda çalışma süresi, bilişsel olgunluk ve katılım değişkenleri toplam varyansın yaklaşık \% 7'sini açıklamaktadır $\left(R^{2}=0.69, p<.05\right)$. Yapılan analiz sonucunda $F=2.654, p=.024$ değerlerine ulaşılmıştır. Bu durumda modelin $p<.05$ düzeyinde anlamlı olduğu bulgusuna ulaşılmıştır. Standartlaştrıımış regresyon katsayılarına ( $\beta$ ) göre, model 2'de bulunan yordayıcı bağımsız değişkenlerin devam bağlıığı üzerindeki göreceli önem sıralaması; katııım boyutu, bilişsel olgunluk boyutu, okulda çalışma süresi, kıdem yılı ve cinsiyettir. Regresyon katsayılarının anlamlılığına ilişkin yapılan analiz sonuçlarına göre, katılım boyutu ve bilişsel olgunluk değişkenlerinin devam bağlılığı üzerinde anlamlı yordayıcılar olduğu görülmektedir ( $p<.05)$ (Tablo 10).

Model 3'te, kıdem yılı, okulda çalışma süresi, bilişsel olgunluk ve katılım değişkenleri toplam varyansın yaklaşık \% 7 'sini açıklamaktadır $\left(R^{2}=0.68, p<.05\right)$. Yapılan analiz sonucunda $F=3.294, p=.012$ değerlerine ulaşılmıştı. Bu durumda modelin $p<.05$ düzeyinde anlamlı olduğu bulgusuna ulaşılmıştr. Standartlaştrılmış regresyon katsayılarına ( $\beta$ ) göre, model 3'de bulunan yordayıcı bağımsız değişkenlerin devam bağlıı̆̆ üzerindeki göreceli önem sıralaması; katılım boyutu, bilişsel olgunluk boyutu, okulda çalışma süresi ve kıdem yılıdır. Regresyon katsayılarının anlamlılığına ilişkin yapılan analiz sonuçlarına göre, katılım boyutu ve bilişsel olgunluk değişkenlerinin örgütsel bağlılık üzerinde anlamlı bir yordayıcısı olduğu görülmektedir ( $p<.05$ ) (Tablo 10).

Model 4'te, okulda çalışma süresi, bilişsel olgunluk ve katılım değişkenleri toplam varyansın yaklaşık \% 6'sını açıklamaktadır $\left(\mathrm{R}^{2}=0.64, \mathrm{p}<.05\right)$. Yapılan analiz sonucunda $\mathrm{F}=4.103, \mathrm{p}=.008$ değerlerine ulaşılmış̧ır. Bu durumda modelin $\mathrm{p}<.05$ düzeyinde anlamlı olduğu bulgusuna ulaşılmıştır. Standartlaştııılmış regresyon katsayılarına ( $\beta$ ) göre, model 4'de bulunan yordayıcı bağımsız değişkenlerin devam bağl1lı̆̆ üzerindeki göreceli önem sıralaması; katılım boyutu, bilişsel olgunluk boyutu ve okulda çalışma süresidir. Regresyon katsayılarının anlamlılı̆̆ına ilişkin yapılan analiz sonuçlarına göre, okulda çalışma süresi, katılım boyutu ve bilişsel olgunluk değiş̧kenlerinin devam bağlılı̆̆ üzerinde anlamlı yordayıcılar olduğu görülmektedir ( $<<.05)$ (Tablo 10).

Tablo 10. Devam Bağlılığı Alt Boyutuna ilişsin Hiyerarşik Regresyon Analizi

\begin{tabular}{|c|c|c|c|c|c|c|}
\hline Model & Değişkenler & $\beta$ & $\mathrm{t}$ & $\mathrm{p}$ & VIF & $\mathrm{R}^{2}$ \\
\hline \multirow{6}{*}{1} & Cinsiyet & -.034 & -.412 & .681 & 1.311 & \multirow{6}{*}{.069} \\
\hline & Kıdem Yılı & -.065 & -.684 & .495 & 1.731 & \\
\hline & Okulda Çalışma Süresi & -.160 & -1.870 & .063 & 1.394 & \\
\hline & Katılım Boyutu & .312 & 2.084 & .039 & 4.282 & \\
\hline & Bilişsel Olgunluk Boyutu & -.235 & -2.031 & .044 & 2.553 & \\
\hline & Yenilikci Boyutu & -.040 & -.272 & .786 & 4.186 & \\
\hline \multirow{5}{*}{2} & Cinsiyet & -.033 & -.398 & .691 & 1.307 & \multirow{5}{*}{.069} \\
\hline & Kıdem Yılı & -.064 & -.677 & .499 & 1.729 & \\
\hline & Okulda Çalışma Süresi & -.159 & -1.873 & .063 & 1.394 & \\
\hline & Katilım Boyutu & .284 & 2.599 & .010 & 2.299 & \\
\hline & Bilişsel Olgunluk Boyutu & -.244 & -2.212 & .028 & 2.336 & \\
\hline \multirow{4}{*}{3} & Kıdem Yılı & -.080 & -.935 & .351 & 1.420 & \multirow{4}{*}{.068} \\
\hline & Okulda Çalışma Süresi & -.157 & -1.852 & .066 & 1.386 & \\
\hline & Katılım Boyutu & .277 & 2.575 & .011 & 2.231 & \\
\hline & Bilişsel Olgunluk Boyutu & -.239 & -2.188 & .030 & 2.310 & \\
\hline \multirow{3}{*}{4} & Okulda Çalışma Süresi & -.197 & -2.701 & .008 & 1.029 & \multirow{3}{*}{.064} \\
\hline & Katilım Boyutu & .272 & 2.532 & .012 & 2.225 & \\
\hline & Bilişsel Olgunluk Boyutu & -.224 & -2.073 & .040 & 2.260 & \\
\hline
\end{tabular}

Araştırma bulgularına göre duygusal bağlılığa ilişkin Durbin Watson istatistik değeri 1.877'dir, yani 2 civarındadır ve hata terimleri arasında korelasyon olmadığı sonucuna ulaşılmıştır. Tablo 11'de VIF değerinin 1 ile 5 arasında olduğu görülmektedir. 5 ve üzeri bir değer bulunmadığı için bağımsız değişkenler arasında korelasyon olmadığı ve değişkenlerin modelde kalmasının uygun olacağı şeklinde yorumlanabilir.

Model I'de, cinsiyet, kıdem yılı, okulda çalışma süresi, bilişsel olgunluk boyutu, katılım boyutu ve yenilikçi boyutu 
değişkenleri toplam varyansın yaklaşık \% 4'ünü açıklamaktadır $\left(R^{2}=0.42, p>.05\right)$. Yapılan analiz sonucunda $F=1.285$, $p=.267$ değerlerine ulaşılmıştır. Bu durumda modelin $p>.05$ düzeyinde anlamlı olmadığı bulgusuna ulaşılmıştr. Standartlaştırılmış regresyon katsayılarına ( $\beta$ ) göre, model 1'de bulunan yordayıcı bağımsız değişkenlerin duygusal bağıı̆ı̆ı üzerindeki göreceli önem sıralaması; bilişsel olgunluk boyutu, cinsiyet, Yenilikçi boyutu, katılım boyutu, okulda çalışma süresi ve kıdem yılıdır. Regresyon katsayılarının anlamlıı̆ı̆ına ilişkin yapılan analiz sonuçlarına göre, değişkenlerin duygusal bağlıık üzerinde anlamlı yordayıcılar olmadığı görülmektedir(p>.05) (Tablo 11).

Model 2'de, cinsiyet, okulda çalışma süresi, bilişsel olgunluk boyutu, katılım boyutu ve yenilikçi boyutu değişkenleri toplam varyansın yaklaşık \% 4'ünü açıklamaktadır $\left(R^{2}=0.41, p>.05\right)$. Yapılan analiz sonucunda $F=1.550, p=.177$ değerlerine ulaşıımıştr. Bu durumda modelin p>.05 düzeyinde anlamlı olmadığı bulgusuna ulaşılmıştır. Standartlaştırılmış regresyon katsayılarına $(\beta)$ göre, model 2'de bulunan yordayıcı bağımsız değişkenlerin duygusal bağlıığı üzerindeki göreceli önem sıralaması; bilişsel olgunluk boyutu, cinsiyet, Yenilikçi boyutu, katlım boyutu ve okulda çalışma süresidir. Regresyon katsayılarının anlamlılığına ilişkin yapılan analiz sonuçlarına göre, değişkenlerin duygusal bağlılık üzerinde anlamlı yordayıcılar olmadığı görülmektedir (p>.05) (Tablo 11).

Model 3'te, cinsiyet, bilişsel olgunluk boyutu, kathlım boyutu ve yenilikçi boyutu değişkenleri toplam varyansın yaklaşık \% 4'ünü açıklamaktadır $\left(R^{2}=0.41, p>.05\right)$. Yapılan analiz sonucunda $F=1.945, p=.105$ değerlerine ulaşılmıştır. Bu durumda modelin $p>.05$ düzeyinde anlamlı olmadığı bulgusuna ulaşılmıştı. Standartlaştırılmış regresyon katsayılarına ( $\beta$ ) göre, model 3'de bulunan yordayııı bağımsız değişkenlerin duygusal bağlıı̆̆ı üzerindeki göreceli önem sıralaması; bilişsel olgunluk boyutu, cinsiyet, yenilikçi boyutu ve kathlım boyutudur. Regresyon katsayılarının anlamlılı̆ına ilişkin yapılan analiz sonuçlarına göre, değişkenlerin duygusal bağılık üzerinde anlamlı yordayıcılar olmadığı görülmektedir (p>.05) (Tablo 11).

Model 4'te, cinsiyet, yenilikçi boyutu ve bilişsel olgunluk boyutu değişkenleri toplam varyansın yaklaşık \% 4'ünü açıklamaktadır $\left(R^{2}=0.41, p>.05\right)$. Yapılan analiz sonucunda $F=2.598, p=.054$ değerlerine ulaşılmıştır. Bu durumda modelin $p>.05$ düzeyinde anlamlı olmadığı bulgusuna ulaşılmıştr. Standartlaştıılmış regresyon katsayılarına ( $\beta$ ) göre, model 4'te bulunan yordayıcı bağımsız değişkenlerin duygusal bağlılığı üzerindeki göreceli önem sıralaması; bilişsel olgunluk boyutu, cinsiyet ve yenilikçi boyutudur. Regresyon katsayılarının anlamlılığına ilişkin yapılan analiz sonuçlarına göre, değişkenlerin duygusal bağlııı üzerinde anlamlı yordayıcılar olmadığı görülmektedir ( $p>.05$ ) (Tablo 11).

Model 5'te, cinsiyet ve bilişsel olgunluk boyutu değişkenleri toplam varyansın yaklaşık \% 4'ünü açıklamaktadır (R2 $=0.38, p<.05$ ). Yapılan analiz sonucunda $F=3.609, p=.029$ değerlerine ulaşılmıştr. Bu durumda modelin $p<.05$ düzeyinde anlamlı olduğu bulgusuna ulaşılmıştı. Standartlaştrıımış regresyon katsayılarına ( $\beta$ ) göre, model $5^{\prime}$ te bulunan yordayıcı bağımsız değişkenlerin duygusal bağlılığı üzerindeki göreceli önem sıralaması; bilişsel olgunluk boyutu ve cinsiyettir. Regresyon katsayılarının anlamlılı̆ına ilişkin yapılan analiz sonuçlarına göre, bilişsel olgunluk alt boyutu değişkeninin duygusal bağlılık üzerinde anlamlı yordayıcı olduğu görülmektedir ( $p<.05$ ) (Tablo 11).

Model 6'da, bilişsel olgunluk boyutu değişkeni toplam varyansın yaklaşık \% 3'ünü açıklamaktadır $\left(R^{2}=0.33, p<\right.$ .05). Yapılan analiz sonucunda $F=6.162, p=.014$ değerlerine ulaşılmıştır. Bu durumda modelin $p<.05$ düzeyinde anlamlı olduğu bulgusuna ulaşılmıştır. Regresyon katsayılarının anlamlıı̆ına ilişkin yapılan analiz sonuçlarına göre, bilişsel olgunluk alt boyutu değişkeninin duygusal bağılık üzerinde anlamlı yordayıcı olduğu görülmektedir ( $p<.05)$ (Tablo 11).

Tablo 11. Duygusal Bağlılık Alt Boyutuna İlişkin Hiyerarşik Regresyon Analizi

\begin{tabular}{|c|c|c|c|c|c|c|}
\hline Model & Değişkenler & $\beta$ & $\mathrm{t}$ & $\mathrm{p}$ & VIF & $\mathrm{R}^{2}$ \\
\hline \multirow{6}{*}{1} & Cinsiyet & .071 & .848 & .397 & .763 & \multirow{6}{*}{.042} \\
\hline & Kıdem Yılı & -.005 & -.050 & .961 & .578 & \\
\hline & Okulda Çalışma Süresi & -.006 & -.066 & .947 & .717 & \\
\hline & Katılım Boyutu & .027 & .175 & .862 & .234 & \\
\hline & Bilişsel Olgunluk Boyutu & .115 & .977 & .330 & .392 & \\
\hline & Yenilikci Boyutu & .066 & .440 & .661 & .239 & \\
\hline \multirow{5}{*}{2} & Cinsiyet & .070 & .915 & .362 & 1.079 & \multirow{5}{*}{.041} \\
\hline & Okulda Çalışma Süresi & -.008 & -.104 & .917 & 1.059 & \\
\hline & Katılım Boyutu & .026 & .175 & .861 & 4.282 & \\
\hline & Bilişsel Olgunluk Boyutu & .115 & .986 & .325 & 2.539 & \\
\hline & Yenilikci Boyutu & .066 & .443 & .658 & 4.182 & \\
\hline
\end{tabular}




\begin{tabular}{lcccccc}
\hline Model & Değişkenler & $\beta$ & $\mathrm{t}$ & $\mathrm{p}$ & $\mathrm{VIF}$ & $\mathrm{R}^{2}$ \\
\hline \multirow{4}{*}{3} & Cinsiyet & .068 & .912 & .363 & 1.050 & \\
& Kathlım Boyutu & .025 & .168 & .867 & 4.258 & .041 \\
& Bilişsel Olgunluk Boyutu & .116 & 1.010 & .314 & 2.500 & \\
\hline \multirow{2}{*}{4} & Yenilikci Boyutu & .067 & .447 & .655 & 4.179 & \\
& Cinsiyet & .071 & .968 & .335 & 1.009 & .041 \\
& Bilişsel Olgunluk Boyutu & .123 & 1.124 & .263 & 2.249 & \\
\hline \multirow{2}{*}{5} & Yenilikci Boyutu & .084 & .769 & .443 & 2.240 & \\
& Cinsiyet & .075 & 1.027 & .306 & 1.004 & .038 \\
\hline
\end{tabular}

Araştırmada bulgularına göre normatif bağlılığa ilişkin Durbin Watson istatistik değeri 2 civarındadır (1.862) ve hata terimleri arasında korelasyon olmadığı sonucuna ulaşılmıştır. Tablo 12'de VIF değerinin 1 ile 5 arasında olduğu görülmektedir. 5 ve üzeri bir değer bulunmadığı için bağımsız değişkenler arasında korelasyon olmadığı ve değişkenlerin modelde kalmasının uygun olacağı şeklinde yorumlanabilir.

Tablo 12. Normatif Bağlılık Alt Boyutuna İlişkin Hiyerarşik Regresyon Analizi

\begin{tabular}{|c|c|c|c|c|c|c|}
\hline Model & Değişkenler & $\beta$ & $\mathrm{t}$ & $\mathrm{p}$ & VIF & $R^{2}$ \\
\hline \multirow{6}{*}{1} & Cinsiyet & -.008 & -.098 & .922 & 1.311 & \multirow{6}{*}{.116} \\
\hline & Kıdem Yılı & -.168 & -1.817 & .071 & 1.731 & \\
\hline & Okulda Çalışma Süresi & .134 & 1.613 & .109 & 1.394 & \\
\hline & Katilım Boyutu & .028 & .190 & .849 & 4.282 & \\
\hline & Bilişsel Olgunluk Boyutu & .307 & 2.729 & .007 & 2.553 & \\
\hline & Yenilikci Boyutu & -.056 & -.391 & .696 & 4.186 & \\
\hline \multirow{5}{*}{2} & Kıdem Yılı & -.172 & -2.054 & .041 & 1.425 & \multirow{5}{*}{.116} \\
\hline & Okulda Çalışma Süresi & .135 & 1.630 & .105 & 1.386 & \\
\hline & Kathlım Boyutu & .025 & .177 & .860 & 4.165 & \\
\hline & Bilişsel Olgunluk Boyutu & .308 & 2.755 & .006 & 2.535 & \\
\hline & Yenilikci Boyutu & -.056 & -.387 & .699 & 4.172 & \\
\hline \multirow{4}{*}{3} & Kıdem Yılı & -.171 & -2.052 & .042 & 1.416 & \multirow{4}{*}{.116} \\
\hline & Okulda Çalışma Süresi & .136 & 1.646 & .102 & 1.382 & \\
\hline & Bilişsel Olgunluk Boyutu & .314 & 2.968 & .003 & 2.286 & \\
\hline & Yenilikci Boyutu & -.038 & -.365 & .715 & 2.234 & \\
\hline \multirow{3}{*}{4} & KIdem Yılı & -.171 & -2.053 & .042 & 1.416 & \multirow{3}{*}{.115} \\
\hline & Okulda Çalışma Süresi & .134 & 1.634 & .104 & 1.379 & \\
\hline & Bilişsel Olgunluk Boyutu & .286 & 4.002 & .000 & 1.044 & \\
\hline \multirow{2}{*}{5} & Kıdem Yılı & -.101 & -1.408 & .161 & 1.044 & \multirow{2}{*}{.102} \\
\hline & Bilişsel Olgunluk Boyutu & .283 & 3.950 & .000 & 1.044 & \\
\hline 6 & Bilişsel Olgunluk Boyutu & .304 & 4.317 & .000 & 1.000 & .092 \\
\hline
\end{tabular}

Model I'de, cinsiyet, kıdem yılı, okulda çalışma süresi, bilişsel olgunluk boyutu, katılım boyutu ve yenilikçi boyutu değişkenleri toplam varyansın yaklaşık \% 12'sini açıklamaktadır $\left(R^{2}=0.116, p<.05\right)$. Yapılan analiz sonucunda $F=3.898$, $\mathrm{p}=.001$ değerlerine ulaşılmıştır. Bu durumda modelin $p<.05$ düzeyinde anlamlı olduğu bulgusuna ulaşılmıştr. Standartlaştııımış regresyon katsayılarına ( $\beta$ ) göre, model 1'de bulunan yordayıcı bağımsız değişkenlerin normatif bağlılık üzerindeki göreceli önem sıralaması; bilişsel olgunluk boyutu, kıdem yılı, okulda çalışma süresi, yenilikçi boyutu, katılım boyutu ve cinsiyettir (Tablo 12).

Regresyon katsayılarının anlamlılı̆ına ilişkin yapılan analiz sonuçlarına göre, bilişsel olgunluk boyutu değişkeni Model 2'de, kıdem yılı, okulda çalışma süresi, bilişsel olgunluk boyutu, katlım boyutu ve yenilikçi boyutu değişkenleri toplam varyansın yaklaşık \% 12 'sini açıklamaktadır $\left(R^{2}=0.116, p<.05\right)$. Yapılan analiz sonucunda $F=4.701, p=.000$ de- 
ğerlerine ulaşılmıştr. Bu durumda modelin $p<.05$ düzeyinde anlamlı olduğu bulgusuna ulaşıımıştır. Standartlaştırılmış regresyon katsayılarına ( $\beta$ ) göre, model 2'de bulunan yordayıcı bağımsız değişkenlerin normatif bağılıı üzerindeki göreceli önem sıralaması; bilişsel olgunluk boyutu, kıdem yılı, okulda çalışma süresi, yenilikçi boyutu ve katılım boyutudur. Regresyon katsayılarının anlamlılı̆ına ilişkin yapılan analiz sonuçlarına göre, bilişsel olgunluk boyutu ve kıdem yılı değişkenlerinin normatif bağlılık üzerinde anlamlı yordayıcılar oldukları görülmektedir ( $p<.05$ ) (Tablo 12).

Model 3'te, kıdem yılı, okulda çalışma süresi, bilişsel olgunluk boyutu ve yenilikçi boyutu değişkenleri toplam varyansın yaklaşık \% 12'sini açıklamaktadır $\left(R^{2}=0.116, p<.05\right)$. Yapılan analiz sonucunda $F=5.901, p=.000$ değerlerine ulaşılmıştır. Bu durumda modelin $p<.05$ düzeyinde anlamlı olduğu bulgusuna ulaşılmıştır. Standartlaştırılmış regresyon katsayılarına ( $\beta$ ) göre, model 3'te bulunan yordayıcı bağımsız değişkenlerin normatif bağlılık üzerindeki göreceli önem sıralaması; bilişsel olgunluk boyutu, kıdem yılı, okulda çalışma süresi ve yenilikçi boyutudur. Regresyon katsayılarının anlamlılığına ilişkin yapılan analiz sonuçlarına göre, bilişsel olgunluk boyutu ve kıdem yılı değişkenlerinin normatif bağlılık üzerinde anlamlı yordayıcılar oldukları görülmektedir ( $p<.05$ ) (Tablo 12).

Model 4'te, kıdem yılı, okulda çalışma süresi ve bilişsel olgunluk boyutu değişkenleri toplam varyansın yaklaşık \% 12 'sini açıklamaktadır $\left(R^{2}=0.115, p<.05\right)$. Yapılan analiz sonucunda $F=7.861, p=.000$ değerlerine ulaşılmıştır. Bu durumda modelin $p<.05$ düzeyinde anlamlı olduğu bulgusuna ulaşılmıştır. Standartlaştırılmış regresyon katsayılarına $(\beta)$ göre, model 4'te bulunan yordayıcı bağımsız değişkenlerin normatif bağlıık üzerindeki göreceli önem sıralaması; bilişsel olgunluk boyutu, kıdem yılı ve okulda çalışma süresidir. Regresyon katsayılarının anlamlılı̆ına ilişkin yapılan analiz sonuçlarına göre, bilişsel olgunluk boyutu ve kıdem yılı değiş̧kenlerinin normatif bağlılık üzerinde anlamlı yordayıcılar oldukları görülmektedir ( $p<.05)$ (Tablo 12).

Model 5'te, kıdem yılı ve bilişsel olgunluk boyutu değişkenleri toplam varyansın yaklaşık \% 10'unu açıklamaktadır $\left(R^{2}=0.102, p<.05\right)$. Yapılan analiz sonucunda $F=10.361, p=.000$ değerlerine ulaşılmıştir. Bu durumda modelin $p<.05$ düzeyinde anlamlı olduğu bulgusuna ulaşılmıştır. Standartlaştrıımış regresyon katsayılarına ( $\beta$ ) göre, model 5 'te bulunan yordayıcı bağımsız değişkenlerin normatif bağlılık üzerindeki göreceli önem sıralaması; bilişsel olgunluk boyutu ve kıdem yılıdır. Regresyon katsayılarının anlamlılığına ilişkin yapılan analiz sonuçlarına göre, bilişsel olgunluk boyutu değişkeninin normatif bağlılık üzerinde anlamlı yordayıcı olduğu görülmektedir $(p<.05)$ (Tablo 12).

Model 6'da, bilişsel olgunluk boyutu değişkeni toplam varyansın yaklaşık \% 9'unu açıklamaktadır ( $R 2=0.092, p<$ .05). Yapılan analiz sonucunda $F=18.638, p=.000$ değerlerine ulaşılmıştır. Bu durumda modelin $p<.05$ düzeyinde anlamlı olduğu bulgusuna ulaşılmıştır. Regresyon katsayılarının anlamlıı̆ına ilişkin yapılan analiz sonuçlarına göre, bilişsel olgunluk boyutu değişkeninin normatif bağılıı üzerinde anlamlı yordayıcı olduğu görülmektedir ( $p<.05$ ) (Tablo 12).

\section{Sonuç ve Tartışma}

Yapılan bu çalışmada, araştırmanın alt problemleri doğrultusunda öğretmenlerin eleştirel düşünme eğilim düzeyleri ve örgütsel bağ|lık düzeyleri incelenmiş ve ölçeklerin alt boyutları arasında anlamlı bir ilişki olup olmadığına, eleştirel düşünme eğilimlerinin örgütsel bağlılık üzerindeki etkisine bakılmıştı. Ayrıca öğretmenlerin sahip olduğu cinsiyet, kıdem ve bulundukları okulda çalışma süresi değişkenlerinin örgütsel bağılıık düzeyini açıklamada anlamlı bir yordayıcı olup olmadıkları analiz edilmiştir.

Çalışmadan elde edilen bulgulara göre, öğretmenlerin örgütsel bağ|ılıklarının orta düzeyde; örgütsel bağlılı̆ın alt boyutlarından duygusal bağılık düzeylerinin yüksek, normatif ve devam bağlılıklarının orta düzeyde olduğu görülmektedir. Bu bağlamda yapılan araştırmanın başka araştırmalar ile tutarlılık gösterdiği görülmektedir (Seyhan, 2014; Ertan 2008; Güçlü, 2006). Atak (2009), öğrenen örgüt ve örgütsel bağlıık arasındaki ilişkiyi araştırdığı tezinde, çalışanların duygusal bağlılık ve normatif bağ|ılık düzeylerinin yüksek düzeyde olduğu, devam bağlılığııı orta düzeye yakın olduğu sonucuna ulaşmıştır. Meyer ve Allen duygusal bağılığı güçlü olan çalışanların, daha yüksek performans göstermek için motive oldukları ve bu çalışanların örgüte normatif ve devam bağlılı̆ı olanlardan daha önemli katkılarda bulunduklarını yaptıkları çalışmayla ortaya koymuşlardır (Meyer ve Allen, 1997). Brown (2003; akt. Tok, 2013), bir örgütte her şeyden önce çalışanların duygusal bağlıı̆̆ının yüksek olmasının beklendiğini belirtmektedir. Sonrasında sırasıyla normatif bağlılı̆̆ ve devam bağııı̆̆ı yüksek olan çalışanların beklendiğini ifade etmektedir. Bu anlamda bakıldığında öğretmenlerin duygusal bağııı̆ının yüksek çıkması sevindirici ve istenilen bir durumdur.

Çalışmadan elde edilen bir diğer bulgu da öğretmenlerin eleştirel düşünme eğilimlerinin yüksek düzeyde olduğudur. Eleştirel düşünme eğilimi alt boyutlarına bakıldığında öğretmenlerin bilişsel olgunluk, katılım ve yenilikçi eleştirel düşünme eğilimlerinin de yüksek düzeyde olduğu görülmektedir. Uluçınar (2012), "Öğretmen Adaylarının Eleştirel Düşünme Eğilimlerinin Demokratik Değerlerini Yordama Düzeyi” adlı çalışmasında ve Deniz (2009), "Öğretmen Adaylarının Eleştirel Düşünme Beceri Düzeyleri Üzerine Bir İnceleme" adlı çalışmasında öğretmen adaylarının eleştirel düşünme 
eğilimlerinin orta düzeyde olduğu bulgusuna ulaşmışlardır. Karademir (2013) ise, "Öğretmen Adaylarının Sorgulama ve Eleştirel Düşünme Becerilerinin Öğretmen Öz Yeterlik Düzeyine Etkisi" adlı çalışmasında öğretmen adaylarının eleştirel düşünme becerilerinin ortalamanın üzerinde olduğu sonucuna ulaşmıştır. Yapılan çalışmalarda farklı sonuçlara ulaşı|masında, çalışmanın örneklem grubunun veya araştırmanın yapıldığı dönemin özelliklerinin etkisi olabilir. Bayat(2014), "Öğretmen Adaylarının Eleştirel Düşünme Düzeyleri ile Akademik Yazma Başarıları Arasındaki İlişki" adlı çalışmasında eleştirel düşünme düzeyleri bakımından en yüksek ortalamanın İngilizce ve Fen Bilgisi Öğretmenliği anabilim dallarında öğrenim gören öğrencilere ait olduğu bulgusuna ulaşmıştir.

Yapılan araştırma sonucunda örgütsel bağılıı üzerinde değişkenlerin göreceli önem sıralaması; eleştirel düşünme eğilimi, kıdem yılı, cinsiyet ve okulda çalışma süresi şeklinde olduğu, eleştirel düşünme eğilimi değişkeninin örgütsel bağlılık üzerinde anlamlı yordayıcı olduğu bulgusuna ulaşılmıştır. Araştırma sonucuna göre cinsiyet değişkeninin örgütsel bağlılık üzerinde anlamlı bir yordayıcı olmadığı anlaşılmaktadır. Literatüre bakıldığında bazı çalışmalarda da duygusal, normatif ve devam bağııık ile çalışanların cinsiyeti arasında anlamlı bir ilişki olmadığı sonucuna ulaşıldığı görülmektedir (Eren ve Durna, 2005; Zeynel, 2014). Bazı çalışmalarda ise araştırmacılar kontrol değişkenlerinden cinsiyet değişkenine göre örgütsel bağııığın farklıık gösterdiği, erkeklerin kadınlardan daha yüksek bir örgütsel bağlılık düzeyine sahip olduğu sonucuna ulaşmışlardır (Aslan ve Bakır, 2014; Emhan, Mengenci, ve Uryan, 2012; Kurşunoğlu, Bakay ve Tanrı̈ğen, 2010). Araştırma bulgularına göre kıdem yılı değişkeninin genel örgütsel bağlılık üzerinde anlamlı bir yordayıcı olmadığı, ancak normatif bağlıık alt boyutu üzerinde anlamlı bir yordayıcı olduğu görülmektedir. Aslan ve Bakır (2014), yaptıkları çalışmada kıdem yılı değişkenine göre, özel ilköğretim okullarında çalışan öğretmenlerin örgütsel bağılığa ilişkin algıları arasında anlamlı bir farklılık bulunmadığını belirtmektedirler. Topaloğlu, Koç ve Yavuz (2008), kıdemleri az olan öğretmenlerin olumsuz çevresel faktörlerine rağmen bağlılık düzeylerinin yüksek olduğu ve yıllar ilerledikçe bağlılılarının düştüğü, ancak meslek hayatının sonuna doğru gelen öğretmenlerde bağ|lık düzeylerinin düşük bir oranda da olsa arttğı sonucuna ulaşmışlardır. Araştırma bulgularına göre okulda çalışma süresinin genel örgütsel bağlılık üzerinde bir etkisi bulunmamaktadır. Ancak devam bağlılığı üzerinde anlamlı yordayıcı olduğu görülmektedir. Kurşunoğlu, Bakay ve Tanrıöğen (2010), öğretmenlerin duygusal, normatif ve devam bağlılıklarının, okuldaki çalışma sürelerine göre anlamlı bir farklılık gösterdiği ve üç bağlılıkta da görev yaptıkları okulda 11 yıl ve üzeri çalışan öğretmenlerin bağlılıklarının daha yüksek olduğu sonucuna ulaşmışlardır.

Bilişsel olgunluk alt boyutu ile normatif bağlılık ve duygusal bağlılık arasında pozitif yönde bir korelasyon olduğu sonucuna ulaşılmıştır. Örgütsel bağlılık alt boyutlarının etkisine bakıldığında devam bağlıığı, duygusal bağlılık ve normatif bağlılık boyutlarında anlamlı bir etki oluşturduğu görülmektedir. Bilişsel olgunluk düzeyi yüksek olan kişi karar alma sürecinde önyargılarının ve kendi eğilimlerinin bilincindedir. Karar alma sürecinde önyargılarının ve kendi eğilimlerinin farkında olan ve problemin çözümünde farklı bakış açılarını göz önünde bulunduran bir bireyin örgüt içinde bir bağlılık geliştirirken olası tüm durumları göz önünde bulundurması söz konusu olabilir. Bu bağlamda yatırımlara ve alternatiflere göre geliştirilen bir bağlılık türü olan devam bağlıı̆̆ını bilişsel olgunluk alt boyutunun etkilemesi olası bir durumdur. Bilişsel olgunluk düzeyi yüksek olan bir birey, kendisinin kim olduğundan, sahip olduğu düşüncenin, çevresinden ve önceki tecrübelerinden etkilendiğinin farkındadır. Staj ve eğitim aldıkları kuruma karşı kendilerini borçlu hissedebilir. Bu durumda örgüte karşı normatif bağlılık geliştirebilir. Çevresinin etkisi altında kalan bir bireyin, örgütte kendi isteğiyle kalmaya devam etmesi ve örgütte kendisini ailenin bir üyesi gibi hissetmesi, başka bir örgütte daha iyi iş koşulları olsa dahi, bulunduğu örgütten duygusal nedenlerle ayrılmaması söz konusu olabilir. Bu tür durumda da duygusal bağlılık geliştirmesi olası bir durumdur.

Araştırma bulgularına göre eleştirel düşünme eğilimi katılım alt boyutu ile duygusal bağlılık ve normatif bağlılık arasında pozitif yönde anlamlı bir ilişki olduğu sonucuna ulaşılış̧tr. Katılım alt boyutu ve yenilikçi alt boyutu, örgütsel bağlıık üzerinde anlamlı bir etki oluşturmamaktadır; ancak, devam bağılığı alt boyutu üzerinde anlamlı bir yordayıcı olduğu görülmektedir. Katlım eğilimi fazla olan bireyler, akıl yürütmek ve becerilerini kullanmak, yargıya varmak ve problem çözmek için yeteneklerini kullanmak isteyen ve kendinden emin olan kişilerdir. Bu kişiler bir problemi çözmeye veya bir yargıya varmaya çalışırken gerçekleştirilen akıl yürütme sürecini açıklayabilmektedirler. Birey, içinde bulunduğu örgütte var olan alternatifleri değerlendirirken akıl yürütür ve kendisi için en uygun alternatifi bulmaya çalışır. Bu bağlamda yatıımlara ve alternatiflere göre geliştirilen bir bağlıık türü olan devam bağ|ılığı üzerinde katılım boyutunun etkili olması beklenen bir durumdur.

Araştırma bulgularına göre yatırımlara ve alternatiflere göre geliştirilen bir bağlılık türü olan devam bağlılığının sağlanmasında eleştirel düşünme alt boyutları olan katlım boyutu ve bilişsel olgunluk alt boyutlarının etkili olduğu sonucuna ulaşıımıştr. Bu bağlamda okullarda personel güçlendirmek için yapılan çalışmaların, becerilerini kullanma, yargıya varma, problem çözmek için yeteneklerini kullanma ve kendinden emin olma gibi kavramların etkili olduğu bilişsel olgunluk ve katılım alt boyutlarına hitap edeceği ve dolayısıyla devam bağlılığının sağlanmasında etkili olacağı düşünül- 
mektedir. Personel güçlendirmenin örgüt kültürünün bir parçası olduğu göz önünde bulundurulduğunda, iş görenler tarafindan kabul görmesi ve örgüt içinde etkin bir şekilde uygulanabilmesinde temel etkenlerden biri de örgütsel bağlıı̆̆ın sağlanmasıdır. Ayrıca görevde yükselme, başarı belgesi gibi çeşitli ödüllendirme unsurlarının daha etkin kullanılmasının da bu doğrultuda etkili olacağı düşünülmektedir. Okullarda yapılacak çeşitli seremonilerin yapılması ve okul dışında da çalışanları bir araya getirecek öğretmenler günü ve çeşitli önemli günlerin kutlanmasını içeren toplantıların yapılması öğretmenlerin duygusal bağlılıklarını arttıracaktır. Ders programlarının adil dağıtılmasının eleştirel düşünme katılım alt boyutu üzerinde etkili olacağı düşünülmektedir.

\section{Kaynakça}

Açıkgöz, G. (2015). Hemşirelerin eleştirel düşünme eğilimlerinin ve profesyonellik davranışlarının belirlenmesi (Yayımlanmamış Yüksek Lisans Tezi). Marmara Üniversitesi Sağlık Bilimleri Enstitüsü, İstanbul.

Allen, N.J. ve Meyer, J.P., (1990). Organizational commitment: Evidence of career stage effects, Journal of Business Research, 26 (1), 46-91.

Arıkan, R. (2004). Araştırma teknikleri ve rapor hazırlama. Ankara: Asil Yayın.

Aslan, M. ve Bakır, A. (2014). Öğretmenlerin okullarındaki örgütsel bağlılı̆a ilişkin görüşleri, The Journal of Academic Social Science Studies, 25(1), 189-206.

Atak, M. (2009). Öğrenen örgüt ve örgütsel bağlılık ilişkisi (Yayımlanmamış Doktora Tezi). Atatürk Üniversitesi Sosyal Bilimler Enstitüsü, Erzurum.

Bayat, N. (2014). Öğretmen Adaylarının Eleştirel Düşünme Düzeyleri ile Akademik Yazma Başarıları Arasındaki Ilişki. Eğitim ve Bilim Dergisi, 39(173), 155-168.

Boylu, Y., Pelit, E. ve Güçer, E. (2007). Akademisyenlerin örgütsel bağlılık düzeyleri üzerine bir araştırma, Finans Politik \& Ekonomik Yorumlar Dergisi, 44(511), 55-75

Bülbül, S. (2016). Örgütsel bağılık ve iş tatmini: Bir kamu kurumunda uygulanması (Yayımlanmamış Yüksek Lisans Tezi). Nişantaşı Üniversitesi Sosyal Bilimler Enstitüsü, İstanbul.

Demircioğlu, E. (2012). Eleştirel düşünme eğilimi ölçeği'nin uyarlama çalışması ve faktör yapısının farklı değişkenlere göre incelenmesi (Yayımlanmamış Yüksek Lisans Tezi). Abant İzzet Baysal Üniversitesi Eğitim Bilimleri Enstitüsü, Bolu.

Deniz, E. (2009). Öğretmen adaylarının eleştirel düşünme beceri düzeyleri üzerine bir inceleme (Yayımlanmamış Yüksek Lisans Tezi). Hacettepe üniversitesi Sosyal bilimler Enstitüsü, Ankara.

Durmuş, B., Yurtkoru, E. S. ve Çinko, M., (2013), Sosyal Bilimlerde SPSS'le Veri Analizi. İstanbul: Beta Yayınları.

Durna, U. ve Eren, V. (2005). Üç bağlılık ekseninde örgütsel bağılıı. Doğuş Üniversitesi Dergisi, 6(2), 210-219.

Emhan, A., Mengenci, C. ve Uryan, Y., (2012). Yapısal eşitlik modeli kullanılarak iş tatmini, örgüt bağılıı̆ı ve çalışan kathımı kavramları arasındaki ilişkilerin analizi: sağık sektöründe görgül bir araştrma, Akdeniz Üniversitesi iïBF Dergisi, 12 (24),125-140.

Emir, S. (2013). Öğretmenlerin düşünme stillerinin eleştirel düşünme eğilimlerini yordama gücü (i̇stanbul-Fatih Örneği), Kuram ve Uygulamada Eğitim Bilimleri. 13(1), 325-347.

Epstein, R. L. (1999). Critical Thinking. Belmont: Wadsworth Publishing Company.

Ertan, H. (2008). Örgütsel bağlıık, iş motivasyonu ve iş performansı arasındaki ilişki: Antalya'da beş yıldızlı otel işletmelerinde bir inceleme (Yayımlanmamış Doktora Tezi). Afyon Kocatepe Üniversitesi sosyal Bilimler Enstitüsü, Afyon.

Facione, P. A., Sanchez, C. A., Facione, N. C., \& Gainen, J. (1995). The disposition toward critical thinking. The Journal of General Education, 44 (1), 1-25.

Göbel, D. Ş. (2013). Sınıf öğretmenlerinin eleştirel düşünme becerisi öğretimi yeterlilikleri ve uygulamaları (Yayınlanmamış yüksek lisans tezi). Sakarya Üniversitesi Eğitim Bilimleri Enstitüsü, Sakarya.

Güçlü, H. (2006). Turizm sektöründe durumsal faktörlerin örgütsel bağlılık üzerindeki etkisi (Yayımlanmamış Doktora Tezi). Anadolu Üniversitesi Sosyal Bilimler Enstitüsü, Eskişehir.

Gül, H. (2002), Örgütsel Bağlıık Yaklaşımlarının Mukayesesi ve Değerlendirmesi, Ege Akademik Bakış Dergisi, Ege Ünv. IïBF Yayınları, 2(2), 37-55.

Gündoğdu, H. (2009). Eleştirel Düşünme ve Eleştirel Düşünme Öğretimine Dair Bazı Yanılgılar. Celal Bayar Üniversitesi Sosyal Bilimler Dergisi, 7(1), 57-74.

Güney, S. (2011). Yönetim ve Organizasyon. Ankara: Nobel Yayın Dağıtım.

Hair, Joseph F. Jr., Black, William C., Babin, Barry J., Anderson, Rolph E. (2010) Multivariate data analysis, New Jersey: Pearson Education.

Hazer, N. (2011). Sosyal bilgiler öğretmenlerinin eleştirel düşünme yeterlilik düzeyleri, Malatya ili örneği (Yayımlanmamış Yüksek Lisans Tezi). Fırat Üniversitesi Eğitim Bilimleri Enstitüsü.

İlsev, A. (1997): Örgütsel bağlıık: Hizmet sektöründe bir araştırma (Yayımlanmamış Yüksek Lisans Tezi). Hacettepe Üniversitesi Sosyal Bilimler Enstitüsü.

İnce, M. ve Gül, H. (2005). Yönetimde yeni bir paradigma: Örgütsel bağlılık. İleri Giden Ofset. Ankara: Çizgi Kitabevi. 
Kalaycı, Ş. (2006). SPSS Uygulamalı Çok değişkenli Istatistik Teknikleri, Ankara: Asil Yayın Dağıtım.

Karademir, Ç. (2013). Öğretmen adaylarının sorgulama ve eleştirel düşünme becerilerinin öğretmen öz yeterlik düzeyine etkisi (Yayımlanmamış Yüksek Lisans Tezi). Adnan Menderes Üniversitesi Sosyal Bilimler Enstitüsü, Aydın.

Karasar, N. (2005). Bilimsel araştırma yöntemleri. Ankara: Nobel Yayın ve Dağıtım.

Kasımoğlu, T. (2013) Öğretmen adaylarında eleştirel düşünme, mantiksal düşünme ve problem çözme becerilerinin çeşitli değişkenler açııından değerlendirilmesi (Yayınlanmamış Yüksek Lisans Tezi). Gazi Üniversitesi Eğitim Bilimleri Enstitüsü, Ankara.

Kılıç, H., Şen A.I, (2014). UF/EMI eleştirel düşünme eğilimi ölçeğini Türkçe'ye uyarlama çalışması. Eğitim ve Bilim Dergisi, 39(176), 1-12.

Kızıltaş, Y. (2011). Sınıf öğretmeni adaylarının ve sınıf öğretmenlerinin eleştirel düşünme eğilimlerinin çeşitli değişkenler açısından incelenmesi: Van ili örneği. (Yayımlanmamış Yüksek Lisans Tezi). Yüzüncü Yıl Üniversitesi Sosyal Bilimler Enstitüsü,Van .

Korkmaz, Ö. (2009). Öğretmenlerin eleştirel düşünme eğilim ve düzeyleri. Kırşehir Eğitim Fakültesi Dergisi, 10(1), 1-13.

Kökdemir, D. (2003). Belirsizlik durumlarında karar verme ve problem çözme. Ankara: Kültür ve Sosyal Dayanışma Vakf Yayınları.

Kurşunoğlu, A., Bakay, E. ve Tanrıöğen, A. (2010). İlköğretim okulu öğretmenlerinin örgütsel bağılıık düzeyleri, Pamukkale Üniversitesi Eğitim Fakültesi Dergisi, 28(11), 101-115.

Küçük, G.(2007). Aday öğretmenlerin eleştirel düşünme eğilimleri ile duygusal zeka düzeyleri arasındaki ilişki (Yayımlanmamış Yüksek Lisans Tezi). Abant İzzet Baysal Üniversitesi Sosyal Bilimler Enstitüsü, Bolu.

Küçük, G.(2007). Aday öğretmenlerin eleştirel düşünme eğilimleri ile duygusal zeka düzeyleri arasındaki ilişki (Yayımlanmamış Yüksek Lisans Tezi). Abant İzzet Baysal Üniversitesi Sosyal Bilimler Üniversitesi, Bolu.

Mowday, R. T., Porter, L. W. ve Steers, R. M. (1982). Employee-organization linkages: The psychology of commitment, absenteeism, and turnover. New York: Academic Press.

O'Reilly, C. ve Chatman, J. (1986). Organizational Commitment and Psychological Attachment: The Effects of Compliance, Identification and Internalization on Prosocial Behaviour. Journal of Applied Psychology, 71( 3), 492-499.

Özkan, S. (2017). Özgün (Authentic) liderliğin duygusal örgütsel bağllık üzerindeki etkisinde işyerindeki esenlik, kolektif yeterlik ve kurumsal itibar değişkenlerinin rolü. (Yayımlanmamış Doktora Tezi). Gebze Teknik Üniversitesi Sosyal Bilimler Enstitüsü, Kocaeli.

Seferoğlu, S. Ve Akbıyık, C. (2006). Eleştirel düşünme ve eğitimi, Hacettepe Üniversitesi Eğitim Fakültesi Dergisi, 30(1), 193-200.

Seyhan, M. (2014). Iş̧letmelerde örgütsel bağlılı ve örgütsel bağlılı̆ı etkileyen faktörler: gümrük memurları üzerine bir araştırma. (Yayımlanmamış Yüksek Lisans Tezi). Trakya Üniversitesi Sosyal bilimler enstitüsü, Edirne.

Şen, N. S.(2016). Okul öncesi eğitimi öğretmen adaylarının eleştirel düşünme eğilimleri, empati kurma becerileri ve mesleki kaygı düzeyleri arasındaki ilişkinin incelenmesi (Yayımlanmamış Yüksek Lisans Tezi). Çanakkale Onsekiz Mart Üniversitesi Eğitim Bilimleri Enstitüsü, Çanakkale.

Tok, T. N. (2004). Illköğretim müfettişlerinin iş doyumu ve örgütsel bağılıkları. (Yayımlanmış Doktora Tezi). Ankara Üniversitesi Eğitim Bilimleri Enstitüsü, Ankara.

Tok, T. N. (2013). Teachers' job satisfaction and organizational commitment in Turkey. International Journal of Engineering and Management Sciences, 4(2), 250-265.

Toksöz, S.(2015). Çalışanların öğrenen örgüt algılarının iş tatmini, örgütsel bağlılık ve örgüt içi girişimcilikleri üzerindeki etkisi: Bilişim sektörü üzerine bir çalışma (Yayımlanmamış Doktora Tezi). Okan Üniversitesi Sosyal Bilimler Enstitüsü, İstanbul .

Topaloğlu, M. Koç, H. ve Yavuz, E. (2008). Öğretmenlerin örgütsel bağlılı̆ının bazı temel faktörler açısından analizi, Kamu İ̧̧ Hukuku ve iktisat Dergisi, 9(4), 1-19.

Toyran, G. (2015). Okul öncesi öğretmen adaylarının yaratıcı düşünme düzeylerinin ve eleştirel düşünme eğilimlerinin bazı değişkenler açııından incelenmesi (Yayımlanmamış Yüksek Lisans Tezi). Dokuz Eylül Üniversitesi Eğitim Bilimleri Enstitüsü, İzmir.

Tuncer, M. A. (2013). Okul yöneticilerinin eleştirel düşünme Eğilimleri ile karar verme stratejileri Arasındaki ilişki, İstanbul ili Maltepe ilçesi örneği (Yayımlanmamış Yüksek Lisans Tezi). Yeditepe Üniversitesi Sosyal Bilimler Enstitüsü, İstanbul.

Türnüklü E. ve Yeşildere, S.(2005). Problem, problem çözme ve eleştirel düşünme, Gazi Üniversitesi Gazi eğitim Fakültesi Dergisi, 25(3).107-123.

Uluçınar, U. (2012). Öğretmen Adaylarının Eleştirel Düşünme Eğilimlerinin Demokratik Değerlerini Yordama Düzeyi. (Yayınlanmamış yüksek lisans tezi). Osmangazi Üniversitesi Eğitim Bilimleri Enstitüsü, Eskişehir.

Varoğlu, G.(2014). Öğretmenlerin sınıf yönetimi anlayışları ile eleştirel düşünme eğilimleri arasındaki ilişkinin incelenmesi, îstanbul ili Beşiktaş ilçesi örneği (Yayımlanmamış Yüksek Lisans Tezi). Yeditepe Üniversitesi Eğitim Bilimleri Enstitüsü, İstanbul.

Vural, M. (2016). Spor federasyonları personelinin örgütsel adalet algıları ile karar verme ve örgütsel bağlılık düzeylerinin araştrılması (Yayımlanmamış Doktora Tezi). Sakarya Üniversitesi Eğitim Bilimleri Enstitüsü, Sakarya.

Yuva E. (2011). Ankara üniversitesi tıp fakültesi cebeci araştırma ve uygulama hastanesi hemşirelerinin eleştirel düşünme eğilim düzeylerinin bazı değişkenler açııından incelenmesi (Yayımlanmamış Yüksek Lisans Tezi). Ankara Üniversitesi Sosyal Bilimler Enstitüsü, Ankara.

Zeynel, E.(2014). Akademisyenlere yönelik mesleki motivasyon, iş tatmini ve örgütsel bağılılık arasındaki ilişkiler üzerine bir araştırma (Yayımlanmamış Doktora Tezi). Süleyman Demirel Üniversitesi Sosyal Bilimler Enstitüsü, Isparta. 